\title{
Synthesis and Properties of Azulene-substituted Donor-Acceptor Chromophores Connected by Arylamine Cores
}

\author{
Taku Shoji, ${ }^{*[a]}$ Erika Shimomura, ${ }^{[a]}$ Mitsuhisa Maruyama, ${ }^{[a]}$ Akifumi Maruyama,${ }^{[a]}$ Shunji Ito, ${ }^{[b]}$ \\ Tetsuo Okujima, ${ }^{[\mathrm{c}]}$ Kozo Toyota, ${ }^{[\mathrm{d}]}$ and Noboru Morita ${ }^{[\mathrm{d}]}$
}

Keywords: Azulene / Arylamine / $\pi$-Conjugate system / Cycloaddition / Redox chemistry /

\begin{abstract}
1-Ethynylazulenes connected by several arylamine cores reacted with tetracyanoethylene (TCNE) and 7,7,8,8-tetracyanoquinodimethane (TCNQ) in a formal $[2+2]$ cycloaddition-cycloreversion reaction to afford the corresponding tetracyanobutadiene (TCBD) and dicyanoquinodimethane (DCNQ) chromophores, respectively, in excellent yields. The intramolecular charge-transfer (ICT) characters between the donor (azulene and arylamine cores) and acceptor (TCBD and DCNQ units) moieties were investigated by $\mathrm{UV} / \mathrm{V}$ is spectroscopy and theoretical calculations.
\end{abstract}

The redox behavior of the novel TCBD and DCNQ derivatives was examined by cyclic voltammetry $(\mathrm{CV})$ and differential pulse voltammetry (DPV), which revealed their multistep electrochemical reduction properties. Moreover, a significant color changes were observed by visible spectroscopy under the electrochemical reduction conditions. [a] Department of Chemistry, Faculty School of Science, Shinshu University, Matsumoto 390-8621, Japan

Fax: +81-263-37-2476

E-mail: tshoji@shinshu-u.ac.jp

[b] Graduate School of Science and Technology, Hirosaki University, Hirosaki 036-8561, Japan

[c] Department of Chemistry and Biology, Graduate School of Science and Engineering, Ehime University, Matsuyama 790-8577, Japan

[d] Department of Chemistry, Graduate School of Science, Tohoku University, Sendai 980-8578, Japan

Supporting information for this article is available on the WWW under http://www.eurjoc.org/ or from the author.

\section{Introduction}

Arylamine derivatives are very important compounds for the development of organic electronic materials, such as light emitting diodes (LED), ${ }^{[1]}$ semiconductors, ${ }^{[2]}$ solar cells, ${ }^{[3]}$ memory devices, ${ }^{[4]}$ and so on. Donor-acceptor derivatives possessing the arylamine moieties have also attracted much interest due to their potentials as organic electronics. ${ }^{[5]}$ Therefore, a variety of these derivatives have been synthesized as shown in the literatures.

Recently, Diederich et al. reported that a variety of alkynes substituted by arylamine moieties reacted with tetracyanoethylene (TCNE) and 7,7,8,8-tetracyanoquinodimethane (TCNQ) to give tetracyanobutadiene (TCBD) and dicyanoquinodimethane (DCNQ) derivatives, respectively, in excellent yields. ${ }^{[6]}$ They have also reported that the new chromophores obtained by the reaction have potentials for the application to third-order nonlinear optics, liquid crystals, and molecular batteries. In the meanwhile, Michinobu et al. have reported the synthesis of polymers with multiple TCBD and DCNQ moieties embedded by arylamine units. ${ }^{[7]}$ The polymers with multiple donor-acceptor moieties might become promising candidates for the application to the semiconductors in organic photovoltaic devices, nonlinear optical materials, and ion sensors.
We have also reported the synthesis and electrochemical properties of TCBD and DCNQ derivatives with azulenyl, ${ }^{[8]}$ 2-oxo- $2 H$-cyclohepta[b]-3-furyl, ${ }^{[9]}$ and ferrocenyl ${ }^{[10]}$ substituents, which have been prepared by the $[2+2]$ cycloaddition-cycloreversion reaction of the corresponding acetylene derivatives with TCNE and TCNQ, respectively. Particularly, azulene-substituted TCBDs represent significant color changes with high reversibility among them under the redox conditions. As well as the azulenyl, 2-oxo-2H-cyclohepta[b]-3-furyl, and ferrocenyl substituents, that were examined by our groups as the end groups, arylamino groups also possess strong electron-donating properties with high reactivities. Thus, the acetylene derivatives connected by the arylamine cores are expected to afford a new series of chromophores with multiple donor-acceptor units by the sequential $[2+2]$ cycloaddition-cycloreversion sequence with TCNE and TCNQ. Furthermore, novel chromophores with multiple donor-acceptor units may exhibit multistage redox behavior by the redox reaction of both donor (i.e., azulene and arylamines) and acceptor moieties.

We describe herein the synthesis of novel azulene-substituted acetylene derivatives connected by several arylamine cores including multiple 1-ethynylazulene units utilizing Sonogashira-Hagihara cross-coupling reaction, as well as the preparation of the novel TCBD and DCNQ chromophores by the [2 +2 ] cycloaddition-cycloreversion reaction of the azulene-substituted acetylene derivatives with TCNE and TCNQ, respectively. The electronic properties of the novel TCBD and DCNQ derivatives connected by the arylamine cores were investigated by absorption spectroscopy, electrochemical analysis and theoretical calculations.

\section{Results and Discussion}


Iodine substituent is a very important functional group in the transition-metal-catalyzed cross-coupling reaction of aromatic compounds, because aryl iodides possess higher reactivity compared with the corresponding bromides and chlorides. ${ }^{[11]}$ However, difficulty in the preparation process declines the general usability of the aryl iodides. Preparation of aromatic iodides is often carried out effectively by using the iodination reagents, such as $\mathrm{I}_{2},{ }^{[12]} \mathrm{ICl}^{[13]}$ and $N$-iodosuccinimide (NIS) ${ }^{[14]}$. However, most of the reagents are toxic or expensive, and/or the reaction with the reagents often requires severe reaction conditions as found in the literatures. $^{12,13,14}$ We have recently developed an efficient iodination procedure using $\mathrm{NaI}$ in the presence of $N$-chlorosuccinimide (NCS) ${ }^{[8 \mathrm{e}, 9 \mathrm{a}, 15]}$ Thus, we have examined the preparation of the starting iodoarylamines 5-8 taking the strategy for the iodination of the arylamines $1-\mathbf{4}$, that require for the next palladium-catalyzed cross-coupling reaction.

Thus, the reaction of $\mathbf{1}$ with $\mathrm{NaI} / \mathrm{NCS}$ in acetic acid and subsequent chromatographic purification of the reaction mixture on silica gel afforded the desired $\mathbf{5}^{[15]}$ in $80 \%$ yield (Scheme 1). Likewise, the reaction of $\mathbf{2}$ and $\mathbf{3}$ with $\mathrm{NaI} / \mathrm{NCS}$ afforded the presumed iodination products $6^{[16]}$ and $7^{[17]}$ in $97 \%$ and $71 \%$ yield, respectively (Schemes 2 and 3). Triiodide derivative $\mathbf{8}^{[18]}$ was also obtained by the similar reaction of $\mathbf{4}$ with $\mathrm{NaI} / \mathrm{NCS}$ in $95 \%$ yield (Scheme 4). The yields of the products in these reactions were comparable to those of the reactions with NIS reported in the literatures. Thus, the present procedure has great advantages for the preparation of iodoarylamines, with respect to the product yields and cost-effectiveness.

Preparation of 1-ethynylazulenes connected by arylamine cores 10-14 was accomplished by palladium-catalyzed alkynylation of 1-ethynylazulene $\mathbf{9}^{[8,19]}$ with the corresponding iodoarylamines 5-8 under Sonogashira-Hagihara conditions. ${ }^{[20]}$ The cross-coupling reaction of 5 with 9 in the presence of $\mathrm{Pd}\left(\mathrm{PPh}_{3}\right)_{4}$ as a catalyst in $\mathrm{THF} / \mathrm{Et}_{3} \mathrm{~N}$ at $50{ }^{\circ} \mathrm{C}$ gave methyl 3-(4-dimethylaminophenylethynyl)-7-isopropylazulene-1-carboxyl ate (10) in $99 \%$ yield.

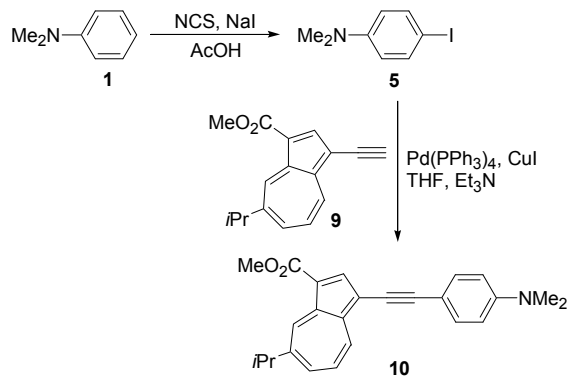

Scheme 1. Synthesis of compound $\mathbf{1 0 .}$

The cross-coupling reaction of 6 with 9 using $\mathrm{Pd}\left(\mathrm{PPh}_{3}\right)_{4}$ as a catalyst and subsequent chromatographic purification on silica gel afforded the desired 4,4'-bis(1-methoxycarbonyl-7-isopropyl-3-azulenylethynyl)diphen ylamine (11) in $94 \%$ yield (Scheme 2). The reaction of 7 with 9 afforded 12 in $85 \%$ yield (Scheme 3 ).

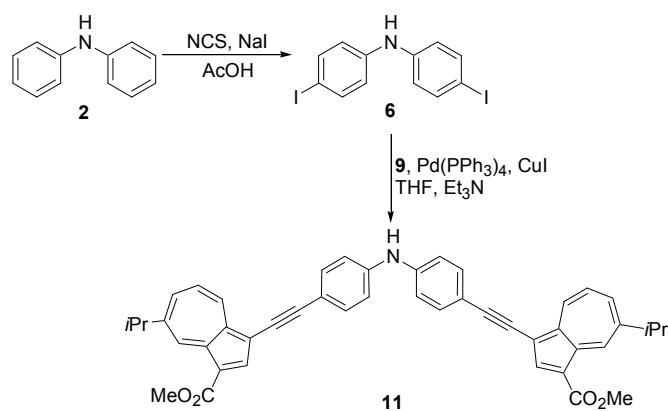

Scheme 2. Synthesis of compound 11.

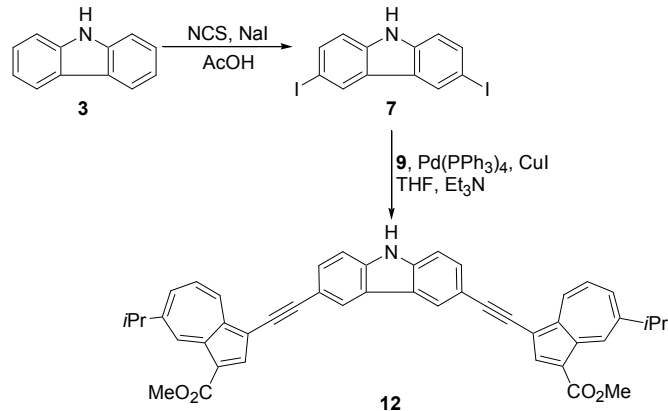

Scheme 3. Synthesis of compound 12.

The cross-coupling reaction of $\mathbf{8}$ with $\mathbf{9}$ in the presence of the Pd-catalyst afforded $\mathbf{1 3}$ in $90 \%$ yield (Scheme 4$)$. These acetylene derivatives 10-13 possess fair solubility toward common organic solvents (e.g., chloroform, dichloromethane, and so on). Moreover, they are stable and showing no decomposition, even after several weeks at room temperature. Thus, these acetylene derivatives are utilized in further transformations for the synthesis of the novel TCBD and DCNQ derivatives owing to their considerable stability and solubility.

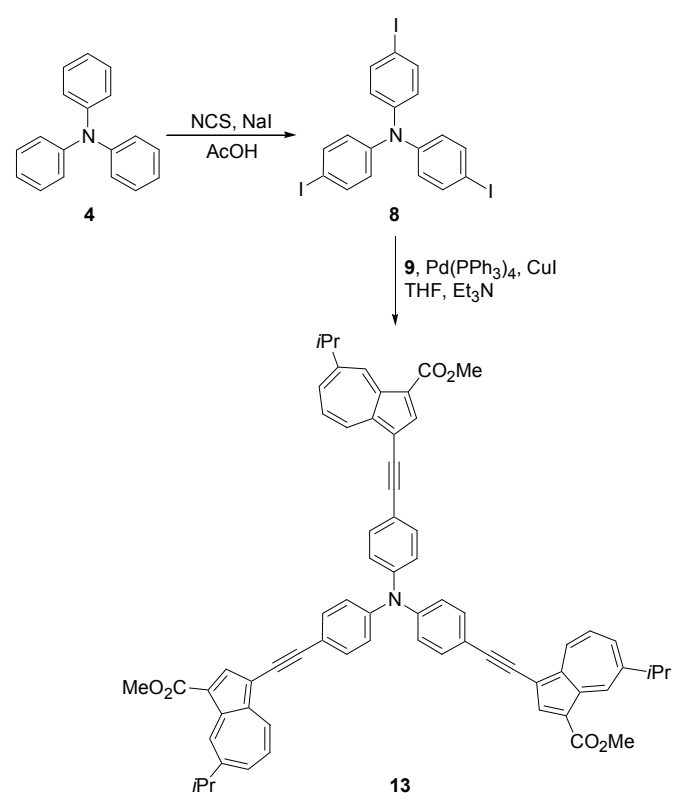

Scheme 4. Synthesis of compound 13. 
The $[2+2]$ cycloaddition-cycloreversion sequence of 10-13 with TCNE and TCNQ was applied for the synthesis of the novel TCBD and DCNQ derivatives. The reaction of $\mathbf{1 0}$ with TCNE in refluxing ethyl acetate yielded $\mathbf{1 4}$ in $97 \%$ yield as a sole product. On the other hand, compounds $\mathbf{1 5}$ and $\mathbf{1 6}$ were generated in $43 \%$ and $48 \%$ yields, respectively, by the reaction of $\mathbf{1 0}$ with TCNQ (Scheme 5). Recently, Diederich et al. have reported the regioselectivity in the $[2+2]$ cycloaddition of $\mathrm{C} \equiv \mathrm{C}$ triple bond with TCNQ correlated to the electron-donating property of the substituent on the ethynyl group. ${ }^{[21]}$ Thus, the less selectivity for the generation of $\mathbf{1 5}$ and $\mathbf{1 6}$ suggests 1-azulenyl group in $\mathbf{1 0}$ possesses almost same electron-donating nature with that of $N, N$-dimethylanilino (DMA) group.

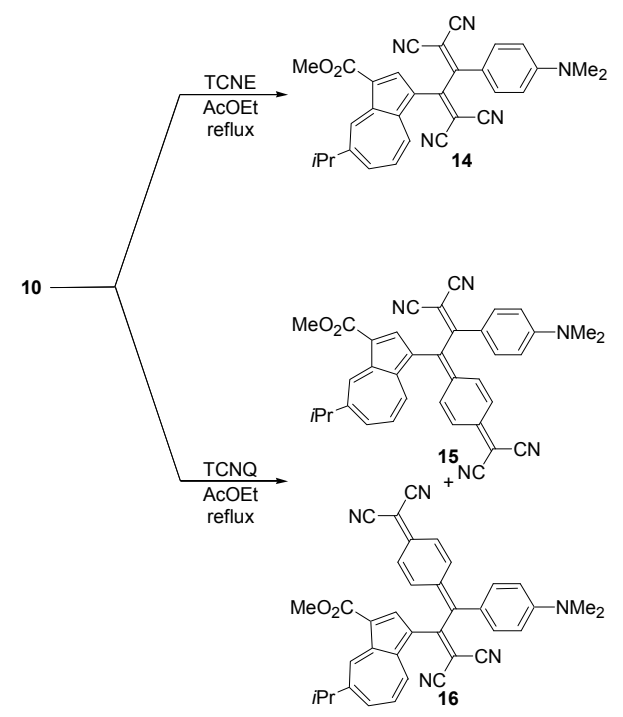

Scheme 5. Reaction of $\mathbf{1 0}$ with TCNE and TCNQ.

The double-addition of TCNE to $\mathbf{1 1}$ gave $\mathbf{1 7}$ in $98 \%$ yield by stirring in the refluxing ethyl acetate. The DCNQ chromophore 18 was also prepared by the one-pot formal $[2+2]$ cycloaddition-cycloreversion reaction of $\mathbf{1 1}$ with TCNQ in $91 \%$ yield (Scheme 6). The TCBD and DCNQ chromophores with carbazole unit 19 and 20 were obtained in $92 \%$ and $84 \%$ yields, respectively, by the $[2+2]$ cycloaddition-cycloreversion reaction of acetylene precursor 12 with TCNE and TCNQ, respectively (Scheme 7).

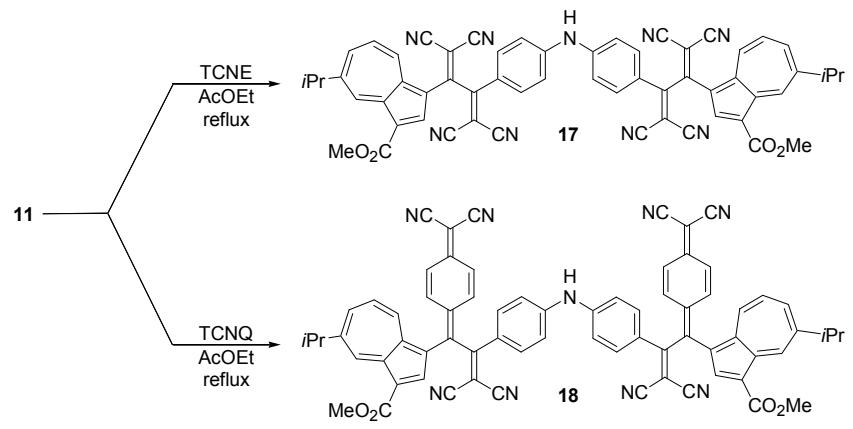

Scheme 6. Reaction of $\mathbf{1 1}$ with TCNE and TCNQ.

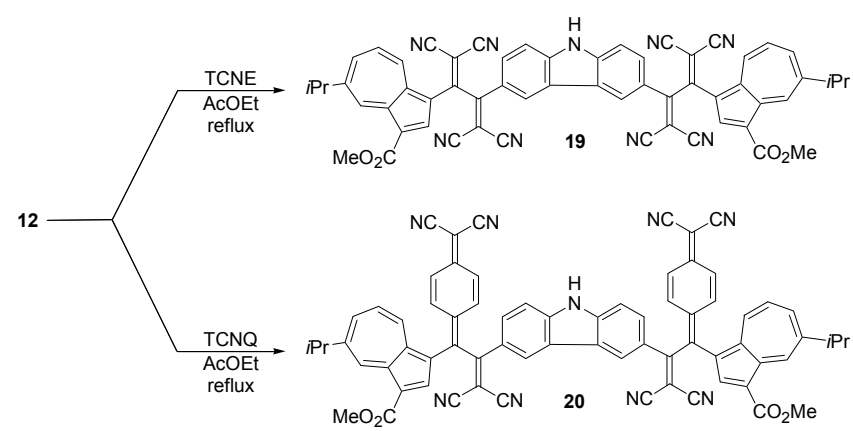

Scheme 7. Reaction of $\mathbf{1 2}$ with TCNE and TCNQ.

Tris-adducts $\mathbf{2 1}$ and $\mathbf{2 2}$ were obtained in excellent yields (21: $90 \% ; 22: 87 \%$ ) by the cycloaddition reaction of TCNE and TCNQ, respectively, with the corresponding alkyne $\mathbf{1 3}$ followed by the cycloreversion reaction (Scheme 8). These novel TCBD and DCNQ derivatives 14-22 are obtained as stable crystals and can be storable in crystalline state under ambient conditions.

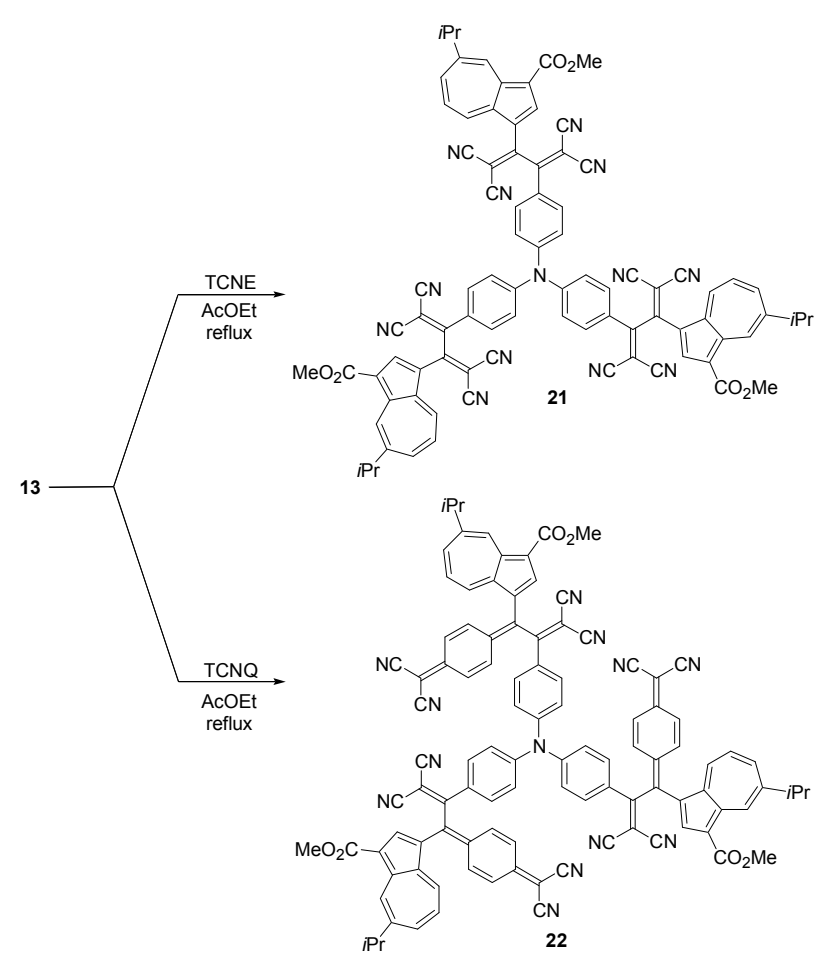

Scheme 8. Reaction of $\mathbf{1 3}$ with TCNE and TCNQ.

\section{Properties}

These new compounds were fully characterized by the spectral data, as shown in the Supporting Information. Assignment of peaks in the ${ }^{1} \mathrm{H}$ and ${ }^{13} \mathrm{C}$ NMR spectra of the compounds was accomplished by NOE, and COSY, HMQC and HMBC experiments. Mass spectra of 10-22 ionized by FAB showed the correct molecular ion peaks. The characteristic stretching vibration band of the acetylene moiety of 10-13 was observed at $v_{\max }=$ 2196-2197 $\mathrm{cm}^{-1}$ in their IR spectra. The TCBD and DCNQ derivatives 14-22 exhibited a characteristic $\mathrm{C} \equiv \mathrm{N}$ stretching band at $v_{\max }=2202-2224 \mathrm{~cm}^{-1}$ in their IR spectra. These results are consistent with the structures of the products. 
UV/Vis spectra of 10-22 are shown in Figures 1, 2, and 3. Their absorption maxima and coefficients $(\log \varepsilon)$ of TCBDs and DCNQs 14-22 in dichloromethane and in hexane including certain amount of dichloromethane to maintain the solubility of the product are summarized in Table 1. The UV/Vis spectra of the acetylene derivatives 10-13 showed characteristic weak absorption bands arising from the azulene system in the visible region. Although the extinction coefficients increased with the number of substituted azulene rings, absorption bands in the visible region of these compounds resemble each other (Figure 1). These results suggest that connection of multiple 1-ethynylazulene moieties in the arylamine cores does not exhibit effective $\pi$-conjugation in these cases.

Table 1. Absorption maxima [nm] and their coefficients (log $\varepsilon$ ) of TCBDs and DCNQs 14-22 in dichloromethane and in hexane, ${ }^{[a-c]}$ and TCBD 23, DCNQ 24, and 25 as references.

\begin{tabular}{ccc}
\hline Sample & $\lambda_{\max }(\log \varepsilon)$ in $\mathrm{CH}_{2} \mathrm{Cl}_{2}$ & $\lambda_{\max }(\log \varepsilon)$ in hexane \\
\hline $\mathbf{1 4}$ & $474(4.49)$ & $459(4.49)^{[\mathrm{a}]}$ \\
$\mathbf{1 5}$ & $631(4.37)$ & $593(4.36)^{[\mathrm{b}]}$ \\
$\mathbf{1 6}$ & $689(4.52)$ & $619(4.48)^{[\mathrm{b}]}$ \\
$\mathbf{1 7}$ & $489(4.81)$ & $459(4.49)^{[\mathrm{a}]}$ \\
$\mathbf{1 8}$ & $628(4.71)$ & $617(4.71)^{[\mathrm{c}]}$ \\
$\mathbf{1 9}$ & $456(4.58)$ & $449(4.55)^{[\mathrm{a}]}$ \\
$\mathbf{2 0}$ & $637(4.70)$ & $626(4.69)^{[\mathrm{c}]}$ \\
$\mathbf{2 1}$ & $503(4.86)$ & $488(4.84)^{[\mathrm{ad}]}$ \\
$\mathbf{2 2}$ & $628(4.85)$ & $617(4.83)^{[\mathrm{c}]}$ \\
$\mathbf{2 3}$ & $462(4.04)$ & - \\
$\mathbf{2 4}^{[8 \mathrm{8}]}$ & $641(4.43)$ & $598(4.42)^{[\mathrm{b}]}$ \\
$\mathbf{2 5}^{[22]}$ & $676(4.56)$ & $600^{[\mathrm{b}]}$ \\
\hline
\end{tabular}

Dichloromethane was included in hexane to maintain solubility of the compounds. [a] Measured in $20 \% \mathrm{CH}_{2} \mathrm{Cl}_{2} /$ hexane. [b] Measured in $10 \%$ $\mathrm{CH}_{2} \mathrm{Cl}_{2} /$ hexane. [c] Measured in $50 \% \mathrm{CH}_{2} \mathrm{Cl}_{2} /$ hexane.

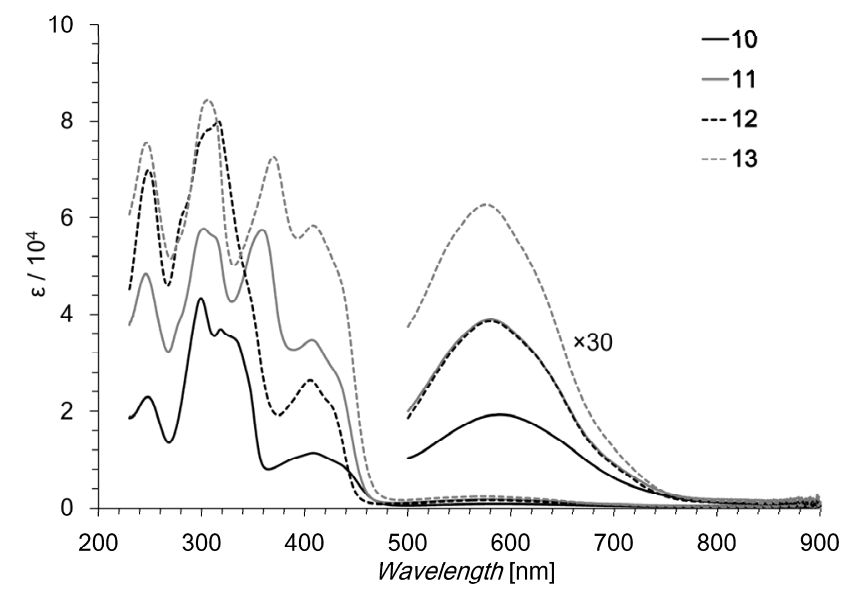

Figure 1. UV-visible spectra of $\mathbf{1 0}$ (black line), $\mathbf{1 1}$ (gray line), $\mathbf{1 2}$ (broken black line), 13 (broken gray line) in dichloromethane.

TCBD 14 exhibited a broad absorption band at $\lambda_{\max }=474 \mathrm{~nm}$. Likewise, TCBD 17 with a diphenylamine core also displayed a broad and strong CT absorption band at $\lambda_{\max }=489 \mathrm{~nm}$. TCBD 21 with a triphenylamine core showed a strong absorption band at $\lambda_{\max }$ $=503 \mathrm{~nm}$. The bathochromic shift in the absorption maxima of TCBDs 14, 17, and 21 in accordance with the increment of the number of substituted TCBD moieties suggest the $\pi$-conjugation of the TCBD moieties with the amine cores as illustrated in Scheme 9 However, absorption maxima of TCBD $19\left(\lambda_{\max }=456 \mathrm{~nm}\right)$ exhibited a hypsochromic shift compared to those of 14, 17, and 21 The absorption maxima of $\mathbf{1 9}$ were nearly equal to that of the simpler TCBD derivative $23\left(\lambda_{\max }=462 \mathrm{~nm}\right)$, although the extinction coefficients still show the trend of increase by the number of TCBD units. These effects are suggested by the less effective $\pi$-conjugation between the central nitrogen atom and the TCBD units in 19, due to the less electron-donating properties of the carbazole spacer to form a quinoidal structure by the resonance forms.

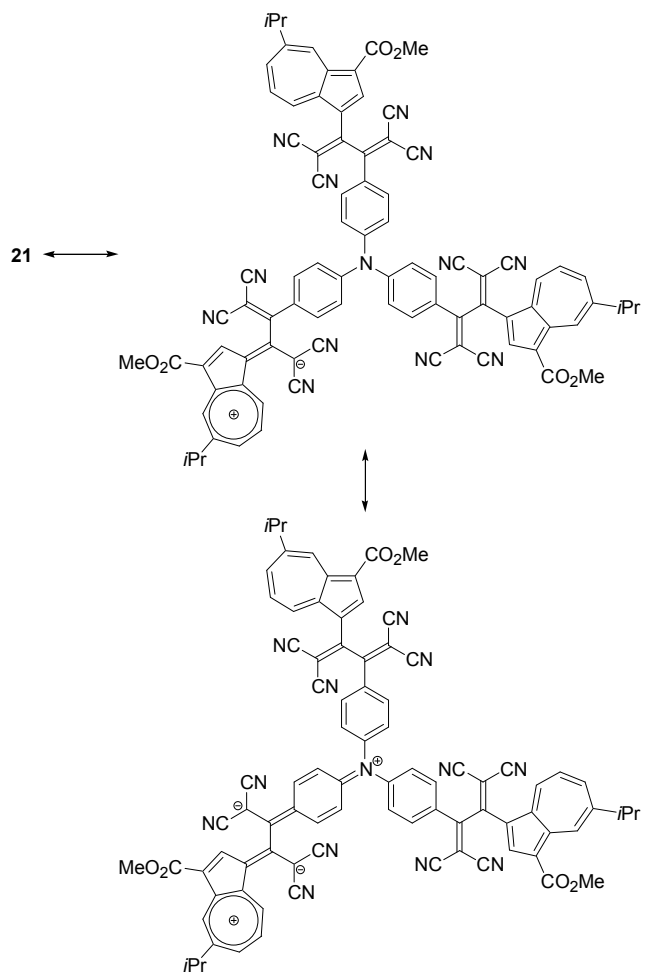

Scheme 9. Presumed resonance structure of 21.

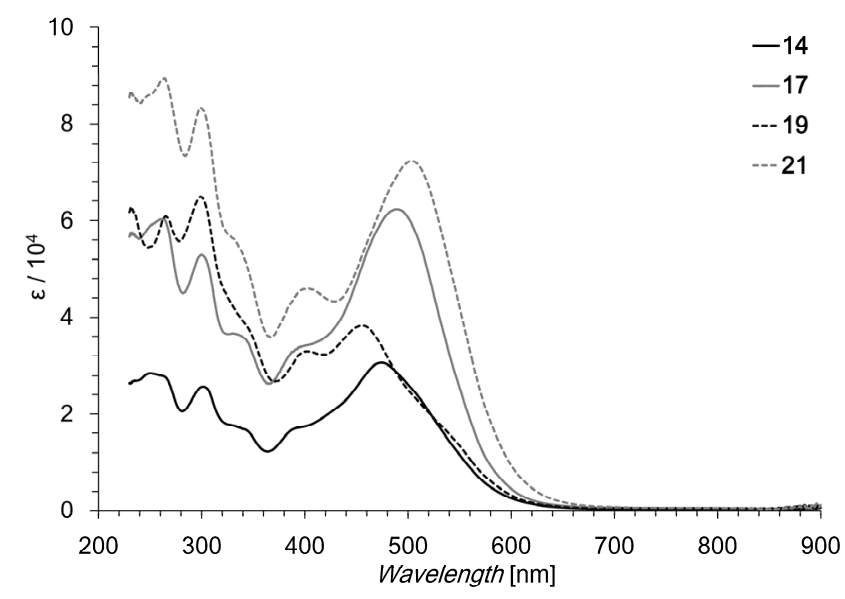

Figure 2. UV-visible spectra of TCBDs 14 (black line), 17 (gray line), 19 (broken black line), and 21 (broken gray line) in dichloromethane.

The DCNQ chromophores $\mathbf{1 5}$ and $\mathbf{1 6}$ exhibited a strong absorption band at $\lambda_{\max }=631 \mathrm{~nm}$ and $\lambda_{\max }=689 \mathrm{~nm}$ in dichloromethane, respectively. Whereas the longest wavelength absorption maximum of $\mathbf{1 5}$ in the same spectral region resembles with that of $\mathbf{2 4}$ at $\lambda_{\max }=641 \mathrm{~nm}$, absorption maximum of $\mathbf{1 6}\left(\lambda_{\max }\right.$ $=689 \mathrm{~nm}$ ) in dichloromethane showed similar value with that of simpler DCNQ $25\left(\lambda_{\max }=676 \mathrm{~nm}\right) .^{[22]}$ These results might be attributed to the effectiveness of the ICT between the DCNQ unit and directly conjugated DMA groups, rather than the cross 
conjugated dicyanomethylidene unit. The absorption maxima of $\mathbf{1 8}$, 20, and 22 (18: $628 \mathrm{~nm}$; 20: $637 \mathrm{~nm}$; 22: $628 \mathrm{~nm}$ ) were nearly equal to that of 15, although the extinction coefficients were in proportion to the number of DCNQ units.

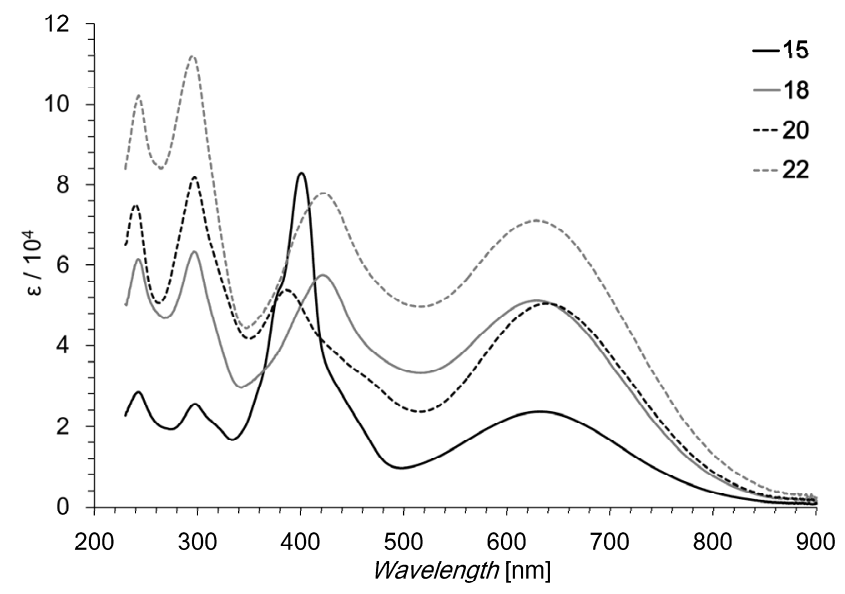

Figure 3. UV-visible spectra of DCNQ 15 (black line), 18 (gray line), $\mathbf{2 0}$ (broken black line) and $\mathbf{2 2}$ (broken gray line) in dichloromethane.
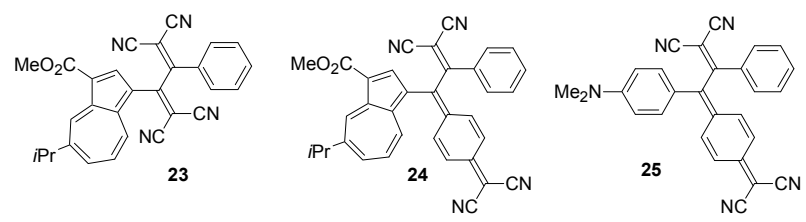

Figure 4. TCBD and DCNQ derivatives 23-25.

Most of the TCBD and DCNQ derivatives showed solvatochromism, when the solvent was changed from dichloromethane to hexane including certain amount of dichloromethane. A noticeable spectral feature of $\mathbf{1 6}$ is the presence of a distinct absorption band at $689 \mathrm{~nm}$ in dhichloromethane, in which compound $\mathbf{1 6}$ exhibits blue-shifts by $70 \mathrm{~nm}\left(\lambda_{\max }=619 \mathrm{~nm}\right)$ in less polar $10 \%$ dichloromethane/hexane, suggesting the ICT nature of this band (Figure 5). ${ }^{[23]}$ The shift value of DCNQs is larger than that of the corresponding TCNE-adducts (TCBDs). These indicate that DCNQs possess high-polarity compared to the corresponding TCBDs, respect to the results from the measurement of UV/Vis spectra.

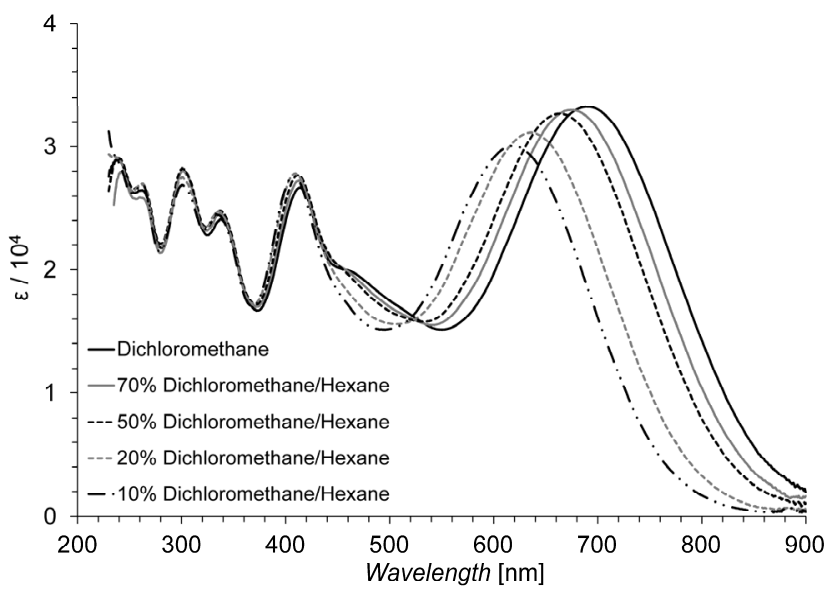

Figure 5. UV-visible spectra of DCNQ 16 in dichloromethane and dichloromethane/hexane.
To elucidate the nature of the absorption bands of 14,15 , and 16 , time-dependent density functional theory (TD-DFT) calculations at the B3LYP/6-31G(d) level were carried out on model compounds 14', 15', and 16', in which the isopropyl group of 14, 15, and 16 was replaced with H-group. ${ }^{[24]}$ The frontier Kohn-Sham orbitals of these compounds are shown in the Supporting Information. Judging from a comparison between the experimental and the theoretical UV/Vis spectra, the absorption maxima of $\mathbf{1 4}$ in the visible region could be assigned to the transition originated from the HOMO located on DMA and the HOMO-1 located at azulene ring to the LUMO that was located on the TCBD moiety. Thus, the broad absorption at $\lambda_{\max }=474 \mathrm{~nm}$ of $\mathbf{1 4}$ could be concluded to the overlapping of the CT absorptions from the 1-azulenyl and DMA moieties to the TCBD unit.

Molecular orbital calculations performed on $15^{\prime}$ by using the B3LYP/6-31G(d) density functional theory exhibited that the absorption band at $\lambda_{\max }=595 \mathrm{~nm}$ of $\mathbf{1 5}$ is considered as overlap of some transitions, which originated from the HOMO located on the 1-azulenyl group and HOMO-1 located on the DMA group to the LUMO and LUMO +2 located on the DCNQ moiety. The $\pi-\pi^{*}$ transitions of the substituted azulene moiety was confirmed from the calculations of $\mathbf{1 5}$ ' observed as the computed value at $\lambda_{\max }=$ $568 \mathrm{~nm}$ with relatively weak strength. ICT of $\mathbf{1 6}^{\prime}$ was also confirmed by the B3LYP/6-31G(d) density functional calculations that the longest absorption band was arisen from the overlapping of some transitions as shown in Table 2. Difference from the results on 15' was the effective contribution of HOMO $\rightarrow$ LUMO (i.e., transition between attached DMA and DCNQ moieties), compared with that from 1-azulenyl group to DCNQ. These results suggest that the longest wavelength absorption band has characteristics depending on the substituted aryl group conjugated directly with DCNQ moiety.

Table 2. Electronic transitions for 14', 15', and 16' derived from the computed values based on B3LYP/6-31G(d) method and experimental values from 14,15 , and 16 .

\begin{tabular}{|c|c|c|c|}
\hline \multirow[t]{2}{*}{ Sample } & \multirow{2}{*}{$\begin{array}{l}\text { Experimental } \\
\lambda_{\max }(\log \varepsilon)\end{array}$} & \multicolumn{2}{|c|}{ Computed Value } \\
\hline & & $\lambda_{\max }$ (strength) & Composition of band ${ }^{[\mathrm{a}]}$ \\
\hline 14' & $474(4.49)^{[\mathrm{b}]}$ & $\begin{array}{l}493(0.0738) \\
480(0.0168)\end{array}$ & $\begin{array}{l}\mathrm{H} \rightarrow \mathrm{L}(0.90) \\
\mathrm{H}-1 \rightarrow \mathrm{L}(0.32) \\
\mathrm{H}-1 \rightarrow \mathrm{L}+1(0.83) \\
\mathrm{H} \rightarrow \mathrm{L}+1(0.37) \\
\mathrm{H}-1 \rightarrow \mathrm{L}(0.84) \\
\mathrm{H}-1 \rightarrow \mathrm{L}+2(0.39)\end{array}$ \\
\hline $15^{\prime}$ & $593(4.36)^{[\mathrm{c}]}$ & $\begin{array}{l}595(0.0358) \\
568(0.0070) \\
515(0.4537)\end{array}$ & $\begin{array}{l}\mathrm{H}-1 \rightarrow \mathrm{L}(0.97) \\
\mathrm{H} \rightarrow \mathrm{L}+1(0.97) \\
\mathrm{H} \rightarrow \mathrm{L}(0.73) \\
\mathrm{H} \rightarrow \mathrm{L}+2(0.52)\end{array}$ \\
\hline $16^{\prime}$ & $619(4.48)^{[\mathrm{c}]}$ & $\begin{array}{l}605(0.3451) \\
566(0.0099) \\
544(0.1058)\end{array}$ & $\begin{array}{l}\mathrm{H} \rightarrow \mathrm{L}(0.78) \\
\mathrm{H} \rightarrow \mathrm{L}+2(0.50) \\
\mathrm{H} \rightarrow \mathrm{L}+1(0.98) \\
\mathrm{H}-2 \rightarrow \mathrm{L}(0.23) \\
\mathrm{H}-1 \rightarrow \mathrm{L}(0.91)\end{array}$ \\
\hline
\end{tabular}

[a] $\mathrm{H}=\mathrm{HOMO}$; $\mathrm{L}=$ LUMO. [b] Measured in $\mathrm{CH}_{2} \mathrm{Cl}_{2}$. [c] Measured in $10 \%$ $\mathrm{CH}_{2} \mathrm{Cl}_{2}$ /hexane.

\section{Electrochemistry}

To clarify the electrochemical properties, the redox behavior of 14-22 was examined by CV and DPV. Measurements were carried out with a standard three-electrode configuration. Tetraethylammonium perchlorate $(0.1 \mathrm{M})$ in benzonitrile was used as a supporting electrolyte with platinum wire and disk as auxiliary and working electrodes, respectively. All measurements were carried out under an argon atmosphere, and potentials were related to an $\mathrm{Ag} / \mathrm{AgNO}_{3}$ reference electrode and $\mathrm{Fc} / \mathrm{Fc}^{+}$as an internal 
reference, which discharges at $+0.15 \mathrm{~V}$ under these conditions for the measurements. A cyclic voltammogram for the reduction of $\mathbf{1 4}$ is shown in Figure 6. The redox potentials (in volts vs. $\mathrm{Ag} / \mathrm{AgNO} 3$ ) of 14-22 are summarized in Table 1.

Table 3. Redox potentials of TCBDs and DCNQs 14-22 bearing arylamine cores, ${ }^{[a, b]}$ and TCBD 23 and DCNQ 24 as references.

\begin{tabular}{llllll}
\hline Sample & Method & $E_{1}{ }^{\text {red }}[\mathrm{V}]$ & $E_{2}{ }^{\text {red }}[\mathrm{V}]$ & $E_{3}^{\text {red }}[\mathrm{V}]$ & $E_{4}^{\text {red }}[\mathrm{V}]$ \\
\hline $\mathbf{1 4}$ & CV & -0.78 & -1.09 & & \\
& (DPV) & $(-0.76)$ & $(-1.07)$ & $(-1.98)$ & \\
$\mathbf{1 5}$ & CV & -0.54 & -0.67 & & \\
& (DPV) & $(-0.52)$ & $(-0.65)$ & $(-1.94)$ & \\
$\mathbf{1 6}$ & CV & -0.53 & -0.67 & & \\
& (DPV) & $(-0.51)$ & $(-0.65)$ & $(-1.87)$ & \\
$\mathbf{1 7}$ & CV & -0.63 & -0.72 & -1.06 & \\
& (DPV) & $(-0.61)$ & $(-0.70)$ & $(-1.04)$ & $(-1.96)$ \\
$\mathbf{1 8}$ & CV & -0.51 & -0.64 & & \\
& (DPV) & $(-0.49)$ & $(-0.62)$ & $(-1.98)$ & \\
$\mathbf{1 9}$ & CV & -0.64 & -0.70 & -1.05 & \\
& (DPV) & $(-0.62)$ & $(-0.68)$ & $(-1.03)$ & $(-1.96)$ \\
$\mathbf{2 0}$ & CV & -0.50 & -0.64 & & \\
& (DPV) & $(-0.48)$ & $(-0.62)$ & $(-2.00)$ & \\
$\mathbf{2 1}$ & CV & -0.58 & -0.68 & -1.02 & \\
$\mathbf{2 2}$ & (DPV) & $(-0.56)$ & $(-0.66)$ & $(-1.00)$ & $(-1.94)$ \\
& CV & -0.46 & -0.61 & & \\
$\mathbf{2 3}$ & (DPV) & $(-0.44)$ & $(-0.59)$ & $(-1.94)$ & \\
$\mathbf{2 4}$ & CV & -0.61 & -1.03 & & \\
& (DPV) & $(-0.59)$ & $(-1.01)$ & $(-1.95)$ & \\
& CV & -0.43 & -0.59 & & \\
& (DPV) & $(-0.41)$ & $(-0.57)$ & $(-0.90)$ & $(-1.93)$ \\
\hline
\end{tabular}

[a] $\mathrm{V}$ vs. $\mathrm{Ag} / \mathrm{AgNO}_{3}, 1 \mathrm{mM}$ in benzonitrile containing $\mathrm{Et}_{4} \mathrm{NClO}_{4}(0.1 \mathrm{M}), \mathrm{Pt}$ electrode (internal diameter: $1.6 \mathrm{~mm}$ ), scan rate $=100 \mathrm{mVs}^{-1}$, and internal reference $\left(\mathrm{Fc} / \mathrm{Fc}^{+}=+0.15 \mathrm{~V}\right)$. [b] Half-wave potential $E^{\mathrm{red}}=\left(E_{\mathrm{pc}}+E_{\mathrm{pa}}\right) / 2$ on $\mathrm{CV}, E_{\mathrm{pc}}$ and $E_{\mathrm{pa}}$ correspond to the cathodic and anodic peak potentials, respectively.

The oxidation of these compounds exhibited voltammograms that were characterized by irreversible oxidation waves on $\mathrm{CV}$, although reversible oxidation wave was frequently observed in the arylamine derivatives due to the generation of stabilized radical cationic species by the electron removal from the nitrogen atom. It might be attributable to the destabilization of radical cationic species by the electron-withdrawing TCBD and DCNQ units.

Electrochemical reduction of TCBD derivatives 14, 17, 19, and 21 displayed a reversible two- or three-stage wave, which contains multi-electron transfer in some cases. As shown in Table 3, the first reduction potentials of $14,17,19$, and 21 depend on the number of TCBD units in the molecule. Electrochemical reduction of $\mathbf{1 4}$ showed a reversible two-step reduction wave with the half-wave potentials of $-0.78 \mathrm{~V}$ and $-1.09 \mathrm{~V}$ upon $\mathrm{CV}$, which can probably be attributed to the formation of a stabilized radical anionic and a dianionic species, respectively (Figure 6).

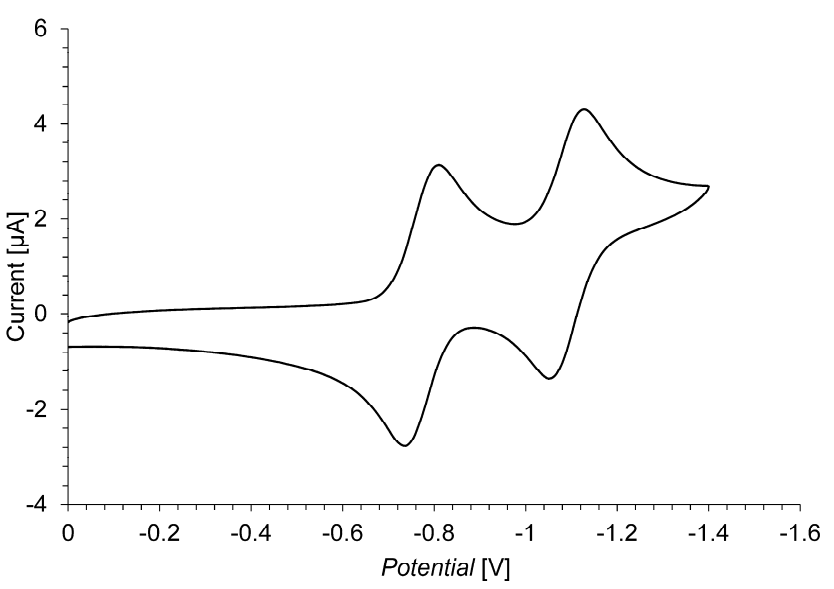

Figure 6. Cyclic voltammogram of $\mathbf{1 4}(1 \mathrm{mM})$ in benzonitrile containing $\mathrm{Et}_{4} \mathrm{NClO}_{4}(0.1 \mathrm{M})$ as a supporting electrolyte; scan rate $=100 \mathrm{mVs}^{-1}$.

A reversible three-stage wave was observed by $\mathrm{CV}$ in bis-adducts $17(-0.63 \mathrm{~V},-0.72 \mathrm{~V}$, and $-1.06 \mathrm{~V})$ and $19(-0.64 \mathrm{~V}$, $-0.70 \mathrm{~V}$, and $-1.05 \mathrm{~V})$, in which the third reduction waves were a two-electron transfer in one step to form a tetraanionic species. The electrochemical reduction of $\mathbf{2 1}$ also exhibited a reversible three-step reduction wave, whose potentials were identified at $-0.58 \mathrm{~V},-0.68 \mathrm{~V}$, and $-1.02 \mathrm{~V}$ by $\mathrm{CV}$. The first reduction potentials of 14, 17, 19, and 21 decreased in the order of the number of TCBD units. This indicates that the connection of multiple TCBD units lowers the LUMO-level and increases the $\pi$-accepting property by the effective $\pi$-conjugation with the arylamine cores.

Electrochemical reduction of DCNQs 15, 16, 18, 20, and 22 also showed a reversible two-stage reduction wave on $\mathrm{CV}$, which could be attributed to the formation of a radical anionic, dianionic species, and so on. The DCNQs 15, 16, 18, 20, and 22 exhibited more negative reduction potentials compared with those of the corresponding TCBD chromophores. These results are ascribed to the higher electron-accepting nature of the DCNQ moieties than that of the corresponding TCBD derivatives. The DMA-substituted TCBD 14 and DCNQ 15 showed more negative reduction potentials than those of the corresponding $23\left(E_{1}{ }^{\text {red }}=-0.61 \mathrm{~V}\right)$ and $24\left(E_{1}{ }^{\text {red }}=-0.43 \mathrm{~V}\right)$. These results should be assumed that the DMA moiety increases LUMO-level due to its higher electron-donating property than that of the phenyl substituent.

We have reported the synthesis of various azulene-substituted redox-active chromophores with the aim of creating stabilized electrochromic materials. ${ }^{[25]}$ In these studies, the TCBD units connected with $\pi$-electron systems exhibit stabilized electrochromism with strong absorptions in visible and near-infrared regions in their two-electron-reduced state. Thus, to examine the color changes during the electrochemical reactions, spectral changes of the new TCBD and DCNQ derivatives were monitored by visible spectroscopy. Constant-current reduction was applied to the solutions of chromophores 14-22, with a platinum mesh as a working electrode and a wire counter-electrode, and visible spectra were measured in benzonitrile containing $\mathrm{Et}_{4} \mathrm{NClO}_{4}$ $(0.1 \mathrm{M})$ as a supporting electrolyte at room temperature under the electrochemical reduction conditions (see the Supporting Information).

The longest absorption band of TCBD 14 at around $470 \mathrm{~nm}$ gradually decreased along with a development of the new absorption band at around $680 \mathrm{~nm}$. The color of the solution gradually changed from red to yellow during the electrochemical reduction, but reverse oxidation of the yellow-colored solution did not regenerate the spectrum of $\mathbf{1 4}$, although good reversibility was observed in the two-step reduction on CV. The poor reversibility of the color changes might be attributable to the instability of the presumed dianionic species, due to the destabilization by the electron-donating DMA unit. The longest absorption bands of the TCBD derivatives with arylamine cores 17, 19, and 21 also gradually decreased, and the color of the solution changed from red to yellow during the electrochemical reduction. The reversible oxidation of the yellow solutions also did not regenerate the spectrum of the corresponding starting compounds (Figure 7). 

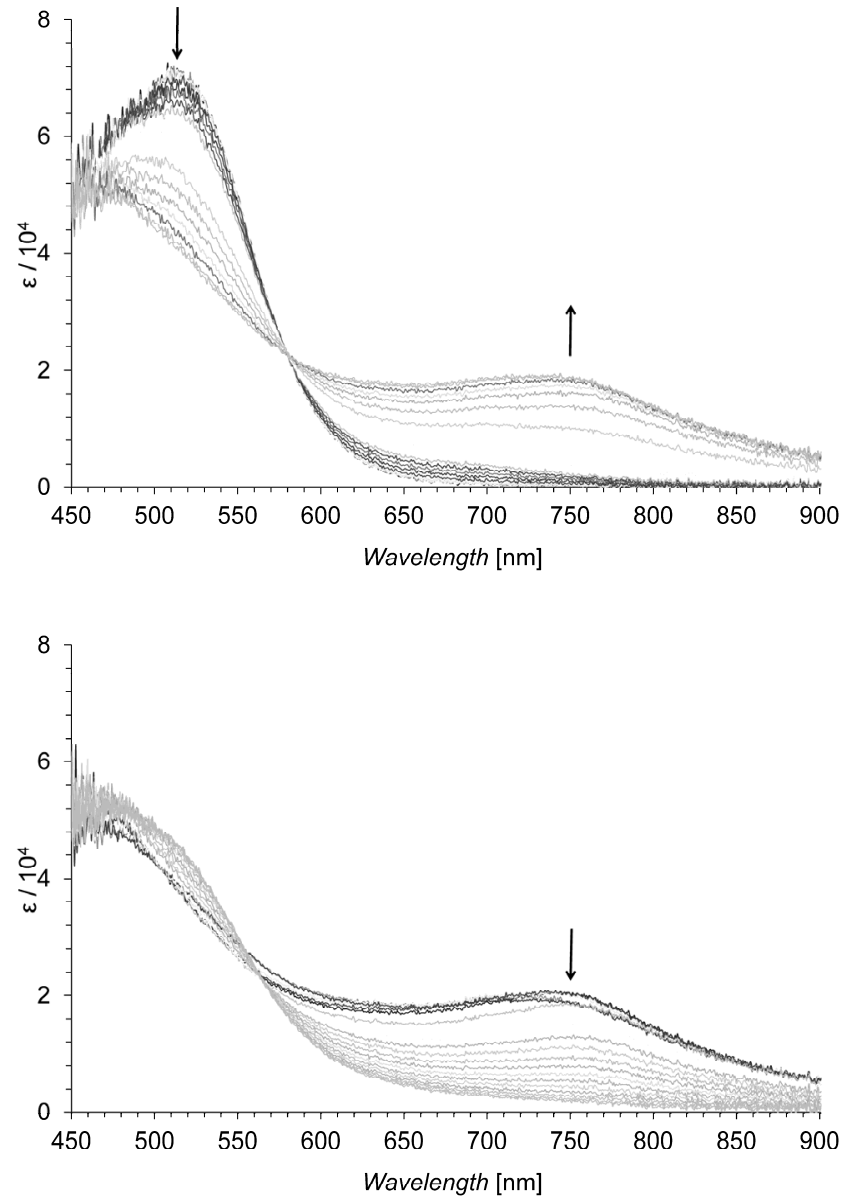

Figure 7. Continuous change in the UV-visble spectrum of 17 : constant-current electrochemical reduction $(100 \mu \mathrm{A}$, top) and reverse oxidation of the reduced species $(100 \mu \mathrm{A}$, bottom) in benzonitrile containing $\mathrm{Et}_{4} \mathrm{NClO}_{4}(0.1 \mathrm{M})$ at $30 \mathrm{sec}$ intervals.

When the spectral changes of DCNQ 15 were monitored during the electrochemical reduction, the absorption in the visible region gradually decreased with the development of new absorption bands at $755 \mathrm{~nm}$ and $860 \mathrm{~nm}$, which are spreading over the near-infrared region (Figure 8, top). The color change should be attributable to the formation of anionic species formed by the two-electron reduction of 15 (Figure 8, bottom). Reverse oxidation of the reduced species decreased the new absorption bands and regenerated the original color of $\mathbf{1 5}$. Presumed redox behavior of 15 is illustrated in Scheme 10. As suggested by the results on the $\mathrm{CV}$, the color change of $\mathbf{1 5}$ should be ascribed by the two electron reduction of the DCNQ unit to form dianionic species, which could be described as closed-shell form as illustrated in Scheme 10. The longest absorption band of DCNQ $\mathbf{1 6}$ gradually decreased, and the color of the solution changed from dark-green to yellow during the electrochemical reduction. Reversible oxidation of the yellow-colored solution regenerated the spectra of the corresponding original compound, but incompletely. The absorption bands of $\mathbf{1 7}$ in the visible region disappeared along with increasing the new absorption maxima around $750 \mathrm{~nm}$ during the electrochemical reduction. The color of the solution gradually changed from red to yellow during the electrochemical reduction. The reverse oxidation of the intermediary yellow solution did not regenerate the parent spectrum of $\mathbf{1 7}$. When the visible spectra of 18 were measured under electrochemical reduction conditions, absorption of $\mathbf{1 8}$ in the visible region gradually decreased along with a color change from green to yellow. However, reverse oxidation did not regenerate the original absorption of $\mathbf{1 8}$. When the visible spectra of $\mathbf{2 0}$ were measured under electrochemical reduction conditions, absorption band of $\mathbf{2 0}$ in the visible region at around $650 \mathrm{~nm}$ gradually decreased. Reverse oxidation of the reduced species decreased the new absorption bands, but did not regenerate the absorption band of $\mathbf{2 0}$, completely. The greenish-blue color of the solution of $\mathbf{2 2}$ changed to yellow during electrochemical reduction, and reverse oxidation of the yellow-colored solution regenerated the visible spectra of $\mathbf{2 2}$.
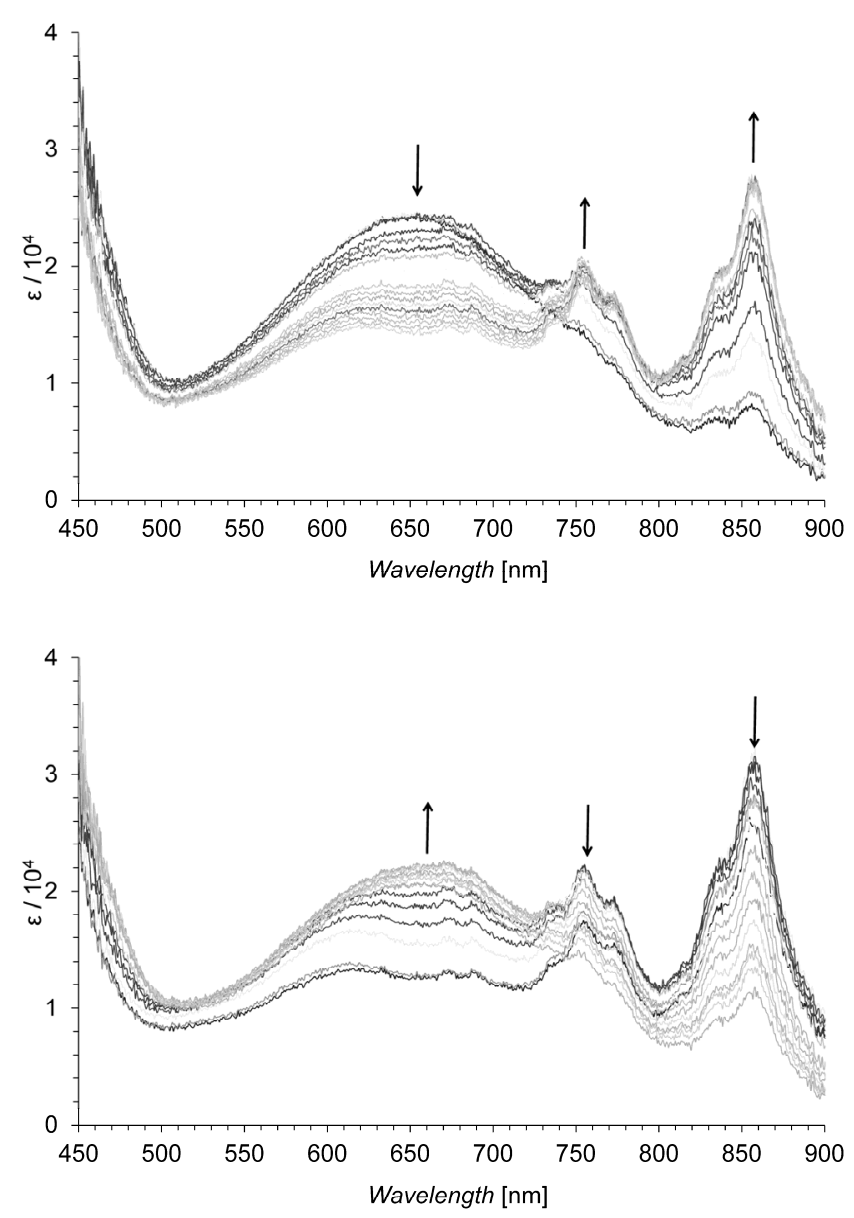

Figure 8. Continuous change in the UV-visble spectrum of 15: constant-current electrochemical reduction $(100 \mu \mathrm{A}$, top) and reverse oxidation of the reduced species $(100 \mu \mathrm{A}$, bottom) in benzonitrile containing $\mathrm{Et}_{4} \mathrm{NClO}_{4}(0.1 \mathrm{M})$ at $30 \mathrm{sec}$ intervals.

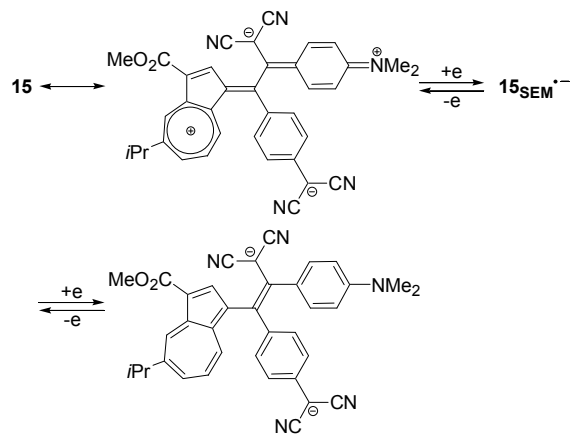

Scheme 10. Presumed redox behavior of DCNQ 15 (SEM is the semiquinone state formed by the single-electron transfer). 
Several arylamine derivatives connected with multiple 1-azulenylethynyl groups 10-14 were prepared by Sonogashira-Hagihara cross-coupling reaction. A series of TCBD and DCNQ chromophores substituted by the 1-azulenyl groups were synthesized in a one-pot reaction consisting of the formal $[2+$ 2] cycloaddition reaction of 10-14 with TCNE and TCNQ, followed by the ring-opening reaction of the initially formed cyclobutene derivatives. Strong intramolecular CT absorption bands were observed in the UV/Vis spectra of these azulene-substituted TCBD and DCNQ derivatives. An analysis by $\mathrm{CV}$ and DPV showed that chromophores 14-21 exhibit a reversible two- or three stage reduction waves. Moreover, a significant color change was observed during the electrochemical reduction. In particular, DCNQ 15 exhibited a significant color change, arising from the generation of a stable dianionic structure during the electrochemical reduction.

\section{Experimental Section}

General: Melting points were determined with a Yanagimoto MPS3 micro melting apparatus and are uncorrected. Mass spectra were obtained with Bruker APEX II instruments. IR and UV/Vis spectra were measured with JASCO FT/IR-4100 and Shimadzu UV-2550 spectrophotometers, respectively. ${ }^{1} \mathrm{H}$ and ${ }^{13} \mathrm{C}$ NMR spectra were recorded with a JEOL ECA-500 spectrometer (at $500 \mathrm{MHz}$ and $125 \mathrm{MHz}$, respectively). Voltammetry measurements were carried out with a BAS $100 \mathrm{~B} / \mathrm{W}$ electrochemical workstation equipped with $\mathrm{Pt}$ working and auxiliary electrodes and a reference electrode formed from $\mathrm{Ag} / \mathrm{AgNO}_{3}(0.01 \mathrm{M})$ in acetonitrile containing tetrabutylammonium perchlorate $(0.1 \mathrm{M})$. Elemental analyses were performed at the Research and Analytical Center for Giant Molecules, Graduate School of Science, Tohoku University.

Compound 10: To a solution of 9 (252 mg, $1.00 \mathrm{mmol}), 5$ (272 mg, 1.10 $\mathrm{mmol})$, and $\mathrm{CuI}(19 \mathrm{mg}, 0.10 \mathrm{mmol})$ in triethylamine $(10 \mathrm{~mL})$ and THF $(10$ $\mathrm{mL})$ was added tetrakis(triphenylphosphine)palladium(0) $(58 \mathrm{mg}, 0.05$ $\mathrm{mmol}$ ). The resulting mixture was stirred at room temperature for $1 \mathrm{~h}$ under an $\mathrm{Ar}$ atmosphere. The reaction mixture was poured into a $10 \% \mathrm{NH}_{4} \mathrm{Cl}$ solution and extracted with $\mathrm{CH}_{2} \mathrm{Cl}_{2}$. The organic layer was washed with brine, dried over $\mathrm{Na}_{2} \mathrm{SO}_{4}$, and concentrated under reduced pressure. The residue was purified by column chromatography on silica gel with $\mathrm{CH}_{2} \mathrm{Cl}_{2}$ to give 10 (368 mg, 99\%) as green crystals. M.p. $154.0-158.0{ }^{\circ} \mathrm{C}\left(\mathrm{CH}_{2} \mathrm{Cl}_{2}\right)$; IR (KBr disk): $v_{\max }=2961(\mathrm{w}), 2197(\mathrm{w}), 1692(\mathrm{~m}), 1602(\mathrm{~m}), 1527(\mathrm{~m})$, 1444 (s), 1367 (m), 1235 (s), 1203 (s), 1122 (w), 1071 (w), 1040 (w), 951 (w), $881(\mathrm{w}), 809(\mathrm{~m}), 783(\mathrm{w}) \mathrm{cm}^{-1}$; UV/Vis $\left(\mathrm{CH}_{2} \mathrm{Cl}_{2}\right): \lambda_{\max }(\log \varepsilon)=248$ (4.36), 300 (4.64), $332 \mathrm{sh}$ (4.54), 409 (4.06), $440 \mathrm{sh}$ (3.91), 589 (2.81) nm; ${ }^{1} \mathrm{H}$ NMR $\left(500 \mathrm{MHz}, \mathrm{CDCl}_{3}\right): \delta_{\mathrm{H}}=9.68(\mathrm{~d}, 1 \mathrm{H}, J=2.0 \mathrm{~Hz}, 4-\mathrm{H}), 8.64(\mathrm{~d}$, $1 \mathrm{H}, J=10.0 \mathrm{~Hz}, 8-\mathrm{H}), 8.42(\mathrm{~s}, 1 \mathrm{H}, 2-\mathrm{H}), 7.76(\mathrm{~d}, 1 \mathrm{H}, J=10.0 \mathrm{~Hz}, 6-\mathrm{H})$, 7.47 (d, 2H, $J=9.0 \mathrm{~Hz}, 2$ ',6'-H), 7.45 (t, 1H, $J=10.0 \mathrm{~Hz}, 7-\mathrm{H}), 6.69$ (d, $\left.2 \mathrm{H}, J=9.0 \mathrm{~Hz}, 3^{\prime}, 5^{\prime}-\mathrm{H}\right), 3.95$ (s, 3H, $\mathrm{CO}_{2} \mathrm{Me}$ ), 3.21 (sept, $2 \mathrm{H}, J=6.5 \mathrm{~Hz}$, $i \mathrm{Pr}), 3.00\left(\mathrm{~s}, 6 \mathrm{H}, \mathrm{NMe}_{2}\right), 1.42$ (d, 6H, $\left.J=6.5 \mathrm{~Hz}, i \mathrm{Pr}\right) \mathrm{ppm} ;{ }^{13} \mathrm{C} \mathrm{NMR}(125$ $\left.\mathrm{MHz}, \mathrm{CDCl}_{3}\right): \delta_{\mathrm{C}}=165.68\left(\mathrm{CO}_{2} \mathrm{Me}\right), 150.08(\mathrm{C}-1$ ') $, 150.01(\mathrm{C}-5), 144.54$ (C-3a), 142.44 (C-2), 141.13 (C-8a), 139.16 (C-6), 138.11 (C-4), 136.39 (C-8), 132.61 (C-2',6'), 127.13 (C-7), 114.88 (C-3), 112.05 (C-3',5'), 110.82 (C-4'), 110.31 (C-1), $94.69(\mathrm{C} \equiv \mathrm{C}), 82.44(\mathrm{C} \equiv \mathrm{C}), 51.24\left(\mathrm{CO}_{2} \mathrm{Me}\right)$, $40.40\left(\mathrm{NMe}_{2}\right), 39.33$ ( $i \mathrm{Pr}$ ), 24.73 (iPr) ppm; HRMS (FAB) calcd for $\mathrm{C}_{25} \mathrm{H}_{25} \mathrm{NO}_{2}[\mathrm{M}]^{+}$371.1880, found 371.1885; Anal. Calcd for $\mathrm{C}_{25} \mathrm{H}_{25} \mathrm{NO}_{2}$ (371.47): C, 80.83; H, 6.78; N, 3.77. found: C, 80.69; H, 6.79; N 3.61.

Compound 11: To a solution of 9 (555 mg, $2.20 \mathrm{mmol}), 6$ (421 mg, 1.00 $\mathrm{mmol})$, and $\mathrm{CuI}(38 \mathrm{mg}, 0.20 \mathrm{mmol})$ in triethylamine $(15 \mathrm{~mL})$ and THF (15 $\mathrm{mL})$ was added tetrakis(triphenylphosphine)palladium $(0)(116 \mathrm{mg}, 0.10$ mmol). The resulting mixture was stirred at $50{ }^{\circ} \mathrm{C}$ for $3 \mathrm{~h}$ under an $\mathrm{Ar}$ atmosphere. The reaction mixture was poured into a $10 \% \mathrm{NH}_{4} \mathrm{Cl}$ solution and extracted with $\mathrm{CH}_{2} \mathrm{Cl}_{2}$. The organic layer was washed with brine, dried over $\mathrm{Na}_{2} \mathrm{SO}_{4}$, and concentrated under reduced pressure. The residue was purified by column chromatography on silica gel with $\mathrm{CH}_{2} \mathrm{Cl}_{2}$ to give $\mathbf{1 1}$ (630 mg, 94\%) as green crystals. M.p. $110.0-114.0{ }^{\circ} \mathrm{C}\left(\mathrm{CH}_{2} \mathrm{Cl}_{2}\right)$; IR $(\mathrm{KBr}$ disk): $v_{\max }=3348(\mathrm{w}), 2957(\mathrm{w}), 2196(\mathrm{w}), 1687(\mathrm{~s}), 1597(\mathrm{~m}), 1508(\mathrm{~s})$, 1447 (s), 1321 (m), 1241 (m), 1206 (s), 1124 (w), 1043 (w), 961 (w), 925 (w), $877(\mathrm{w}), 818(\mathrm{~m}), 765(\mathrm{~m}) \mathrm{cm}^{-1}$; UV/Vis $\left(\mathrm{CH}_{2} \mathrm{Cl}_{2}\right): \lambda_{\max }(\log \varepsilon)=246$ (4.69), $276 \mathrm{sh}$ (4.57), 302 (4.76), $312 \mathrm{sh}$ (4.75), 358 (4.76), 407 (4.54), 434 sh (4.42), $580(3.11) \mathrm{nm} ;{ }^{1} \mathrm{H}$ NMR $\left(500 \mathrm{MHz}, \mathrm{CDCl}_{3}\right): \delta_{\mathrm{H}}=9.72(\mathrm{~d}, 2 \mathrm{H}, J$ $=1.5 \mathrm{~Hz}, 4-\mathrm{H}), 8.65(\mathrm{~d}, 2 \mathrm{H}, J=10.0 \mathrm{~Hz}, 8-\mathrm{H}), 8.46(\mathrm{~s}, 2 \mathrm{H}, 2-\mathrm{H}), 7.79(\mathrm{~d}$, $2 \mathrm{H}, J=10.0 \mathrm{~Hz}, 6-\mathrm{H}), 7.53$ (d, 4H, $J=8.5 \mathrm{~Hz}, 2^{\prime}, 2^{\prime}, 6$, 6"'-H), 7.49 (t, 2H, $J=10.0 \mathrm{~Hz}, 7-\mathrm{H}), 7.10$ (d, 2H, $J=8.5 \mathrm{~Hz}, 3$ ',3", 5', 5"-H), 5.99 (s, 1H, NH), $3.96\left(\mathrm{~s}, 6 \mathrm{H}, \mathrm{CO}_{2} \mathrm{Me}\right.$ ), 3.22 (sept, $\left.2 \mathrm{H}, J=6.5 \mathrm{~Hz}, i \mathrm{Pr}\right), 1.42(\mathrm{~d}, 12 \mathrm{H}, J=6.5$ $\mathrm{Hz}, i \mathrm{Pr}) \mathrm{ppm} ;{ }^{13} \mathrm{C} \mathrm{NMR}\left(125 \mathrm{MHz}, \mathrm{CDCl}_{3}\right): \delta_{\mathrm{C}}=165.52\left(\mathrm{CO}_{2} \mathrm{Me}\right), 150.34$ (C-5), 144.63 (C-3a or 8a), 142.53 (C-2), 142.01 (C-3a or 8a), 141.15 (C-1',1'), 139.23 (C-6), 138.19 (C-4), 136.23 (C-8), 132.68 (C-2',2”,6',6”), 127.27 (C-5), 117.54 (C-3',3”,5',5”), 116.27 (C-4',4”), 114.94 (C-3), $109.52(\mathrm{C}-1), 93.76(\mathrm{C} \equiv \mathrm{C}), 83.64(\mathrm{C} \equiv \mathrm{C}), 51.15\left(\mathrm{CO}_{2} \mathrm{Me}\right), 39.20(i \operatorname{Pr})$, 24.58 (iPr) ppm; HRMS (FAB) calcd for $\mathrm{C}_{46} \mathrm{H}_{39} \mathrm{NO}_{4}^{+}[\mathrm{M}]^{+} 669.2874$, found 669.2872; Anal. Calcd for $\mathrm{C}_{46} \mathrm{H}_{39} \mathrm{NO}_{4} \cdot 1 / 2 \mathrm{H}_{2} \mathrm{O}$ (669.81): C, 81.39; H, 5.94; N, 2.06. found: C, $81.41 ; \mathrm{H}, 5.94 ; \mathrm{N}, 2.05$.

Compound 12: To a solution of 9 (555 mg, $2.20 \mathrm{mmol}), 7$ (419 mg, 1.00 $\mathrm{mmol})$, and CuI (38 mg, $0.20 \mathrm{mmol})$ in triethylamine $(15 \mathrm{~mL})$ and THF (15 $\mathrm{mL})$ was added tetrakis(triphenylphosphine)palladium $(0)(116 \mathrm{mg}, 0.10$ mmol). The resulting mixture was stirred at $50{ }^{\circ} \mathrm{C}$ for $5 \mathrm{~h}$ under an $\mathrm{Ar}$ atmosphere. The reaction mixture was poured into a $10 \% \mathrm{NH}_{4} \mathrm{Cl}$ solution and extracted with $\mathrm{CH}_{2} \mathrm{Cl}_{2}$. The organic layer was washed with brine, dried over $\mathrm{Na}_{2} \mathrm{SO}_{4}$, and concentrated under reduced pressure. The residue was purified by column chromatography on silica gel with $\mathrm{CH}_{2} \mathrm{Cl}_{2}$ to give $\mathbf{1 2}$ (568 mg, 85\%) as green crystals. M.p. $135.0-139.0{ }^{\circ} \mathrm{C}\left(\mathrm{CH}_{2} \mathrm{Cl}_{2}\right)$; IR $(\mathrm{KBr}$ disk): $v_{\max }=3348(\mathrm{w}), 2956(\mathrm{w}), 2874(\mathrm{w}), 2196(\mathrm{w}), 1686(\mathrm{~s}), 1603(\mathrm{w})$, 1477 (s), 1446 (s), 1278 (w), 1245 (m), 1214 (s), 1169 (m), 1125 (m), 1043 $(\mathrm{w}), 877(\mathrm{w}), 807(\mathrm{~m}), 767(\mathrm{~m}) \mathrm{cm}^{-1}$; UV/Vis $\left(\mathrm{CH}_{2} \mathrm{Cl}_{2}\right): \lambda_{\max }(\log \varepsilon)=249$ (4.84), $282 \mathrm{sh}$ (4.79), $305 \mathrm{sh}$ (4.89), 316 (4.90), 406 (4.42), $425 \mathrm{sh}$ (4.33), $581(3.11) \mathrm{nm} ;{ }^{1} \mathrm{H}$ NMR $\left(500 \mathrm{MHz}, \mathrm{CDCl}_{3}\right): \delta_{\mathrm{H}}=9.72(\mathrm{~d}, 2 \mathrm{H}, J=2.0 \mathrm{~Hz}$, 4-H), 8.73 (d, 2H, $J=10.0 \mathrm{~Hz}, 8-\mathrm{H}), 8.50$ (s, 2H, 2-H), 8.35 (s, 2H, $\left.4^{\prime}, 5^{\prime}-\mathrm{H}\right), 8.32$ (s, 1H, NH), 7.80 (d, 2H, $\left.J=10.0 \mathrm{~Hz}, 6-\mathrm{H}\right), 7.68$ (d, 2H, $J=$ $\left.8.5 \mathrm{~Hz}, 2^{\prime}, 7^{\prime}-\mathrm{H}\right), 7.52$ (t, 2H, $\left.J=10.0 \mathrm{~Hz}, 7-\mathrm{H}\right), 7.42$ (d, 2H, $J=8.5 \mathrm{~Hz}$, 1', 8'-H), 3.97 (s, 6H, $\mathrm{CO}_{2} \mathrm{Me}$ ), 3.23 (sept, 2H, $\left.J=6.5 \mathrm{~Hz}, i \operatorname{Pr}\right), 1.43$ (d, $12 \mathrm{H}, J=6.5 \mathrm{~Hz}, i \mathrm{Pr}) \mathrm{ppm} ;{ }^{13} \mathrm{C} \mathrm{NMR}\left(125 \mathrm{MHz}, \mathrm{CDCl}_{3}\right): \delta_{\mathrm{C}}=165.59$ $\left(\mathrm{CO}_{2} \mathrm{Me}\right), 150.32$ (C-5), 144.71 (C-3a), 142.56 (C-2), 141.17 (C-8a), 139.24 (C-6), 138.19 (C-4), 136.31 (C-8), 129.80 (C-2',7'), 127.30 (C-7), 123.84 (C-2), 123.10 (C-4a',4b'), 115.20 (C-8a',9a'), 114.93 (C-3), 110.90 (C-1',8'), $109.68(\mathrm{C}-1), 94.58(\mathrm{C} \equiv \mathrm{C}), 83.04(\mathrm{C} \equiv \mathrm{C}), 51.17\left(\mathrm{CO}_{2} \mathrm{Me}\right), 39.22$ (iPr), 24.60 (iPr) ppm; HRMS (FAB) calcd for $\mathrm{C}_{46} \mathrm{H}_{37} \mathrm{NO}_{4}^{+}[\mathrm{M}]^{+} 667.2718$, found 667.2703; Anal. Calcd for $\mathrm{C}_{46} \mathrm{H}_{37} \mathrm{NO}_{4} \cdot 1 / 2 \mathrm{H}_{2} \mathrm{O}$ (667.79): C, 81.63; $\mathrm{H}$, 5.66; N, 2.07. found: C, 81.60; H, 5.64; N, 2.05 .

Compound 13: To a solution of $9(833 \mathrm{mg}, 3.30 \mathrm{mmol}), \mathbf{8}(623 \mathrm{mg}, 1.00$ $\mathrm{mmol})$, and CuI (57 mg, $0.30 \mathrm{mmol})$ in triethylamine $(15 \mathrm{~mL})$ and THF (15 $\mathrm{mL})$ was added tetrakis(triphenylphosphine)palladium(0) (173 mg, 0.15 mmol). The resulting mixture was stirred at $50{ }^{\circ} \mathrm{C}$ for $6 \mathrm{~h}$ under an $\mathrm{Ar}$ atmosphere. The reaction mixture was poured into a $10 \% \mathrm{NH}_{4} \mathrm{Cl}$ solution and extracted with $\mathrm{CH}_{2} \mathrm{Cl}_{2}$. The organic layer was washed with brine, dried over $\mathrm{Na}_{2} \mathrm{SO}_{4}$, and concentrated under reduced pressure. The residue was purified by column chromatography on silica gel with $\mathrm{CH}_{2} \mathrm{Cl}_{2}$ to give $\mathbf{1 3}$ (897 mg, 90\%) as green crystals. M.p. $131.0-133.0{ }^{\circ} \mathrm{C}\left(\mathrm{CHCl}_{3} / \mathrm{MeOH}\right)$; IR (KBr disk): $v_{\max }=2957(\mathrm{w}), 2196(\mathrm{w}), 1693(\mathrm{~s}), 1593(\mathrm{w}), 1496(\mathrm{~s}), 1446$ (s), $1381(\mathrm{w}), 1317(\mathrm{~m}), 1280(\mathrm{~m}), 1245$ (m), 1204 (s), 1123 (m), 1044 (w), 958 (w), 919 (w), 877 (w), 831 (m), 776 (m), 726 (w) $\mathrm{cm}^{-1}$; UV/Vis $\left(\mathrm{CH}_{2} \mathrm{Cl}_{2}\right): \lambda_{\max }(\log \varepsilon)=247$ (4.88), 306 (4.93), 370 (4.86), 408 (4.77), 433 $\mathrm{sh}$ (4.68), 576 (3.32) nm; ${ }^{1} \mathrm{H}$ NMR (500 MHz, $\left.\mathrm{CDCl}_{3}\right): \delta_{\mathrm{H}}=9.72(\mathrm{~d}, 3 \mathrm{H}, J$ 
$=1.5 \mathrm{~Hz}, 4-\mathrm{H}), 8.65(\mathrm{~d}, 3 \mathrm{H}, J=10.0 \mathrm{~Hz}, 8-\mathrm{H}), 8.46(\mathrm{~s}, 3 \mathrm{H}, 2-\mathrm{H}), 7.80(\mathrm{~d}$, $3 \mathrm{H}, J=10.0 \mathrm{~Hz}, 6-\mathrm{H}), 7.52$ (d, 6H, $\left.J=8.5 \mathrm{~Hz}, 3^{\prime}, 5^{\prime}-\mathrm{H}\right), 7.50$ (dd, $3 \mathrm{H}, J=$ 10.0, $10.0 \mathrm{~Hz}, 7-\mathrm{H}), 7.14$ (d, 6H, J = 8.5 Hz, 2',6'-H), 3.96 (s, 9H, $\left.\mathrm{CO}_{2} \mathrm{Me}\right)$, 3.24 (sept, $3 \mathrm{H}, J=7.0 \mathrm{~Hz}, i \operatorname{Pr}), 1.48(\mathrm{~d}, 18 \mathrm{H}, J=7.0 \mathrm{~Hz}, i \operatorname{Pr}) \mathrm{ppm} ;{ }^{13} \mathrm{C}$ NMR $\left(125 \mathrm{MHz}, \mathrm{CDCl}_{3}\right): \delta_{\mathrm{C}}=165.45\left(\mathrm{CO}_{2} \mathrm{Me}\right), 150.47(\mathrm{C}-5), 146.38$ (C-1'), 144.69 (C-3a), 142.60 (C-2), 141.19 (C-8a), 139.28 (C-6), 138.25 (C-4), 136.20 (C-8), 132.51 (C-3',5'), 127.37 (C-7), 124.07 (C-2',6'), 118.51 (C-4'), 114.99 (C-3), 109.24 (C-1), $93.49(\mathrm{C} \equiv \mathrm{C}), 84.63(\mathrm{C} \equiv \mathrm{C})$, $51.18\left(\mathrm{CO}_{2} \mathrm{Me}\right), 39.24(i \mathrm{Pr}), 24.61(i \mathrm{Pr}) \mathrm{ppm}$; HRMS (FAB) calcd for $\mathrm{C}_{69} \mathrm{H}_{57} \mathrm{NO}_{6}^{+}[\mathrm{M}]^{+}$995.4181, found 995.4185; Anal. Calcd for $\mathrm{C}_{69} \mathrm{H}_{57} \mathrm{NO}_{6} \cdot 1 / 10 \mathrm{CHCl}_{3}$ (996.19): C, 82.32; H, 5.71; N, 1.39. found: C, 82.27 ; H, $5.81 ; \mathrm{N} 1.41$

Compound 14: To a solution of $\mathbf{1 0}(186 \mathrm{mg}, 0.50 \mathrm{mmol})$ in ethyl acetate (5 $\mathrm{mL}$ ) was added TCNE (77 $\mathrm{mg}, 0.60 \mathrm{mmol})$. The resulting mixture was refluxed for $1 \mathrm{~h}$ under an Ar atmosphere. The solvent was removed under reduced pressure. The residue was purified by column chromatography on silica gel with $\mathrm{CH}_{2} \mathrm{Cl}_{2}$ /ethyl acetate (20:1) to give $\mathbf{1 4}(242 \mathrm{mg}, 97 \%)$ as red crystals. M.p. $159.0-162.0{ }^{\circ} \mathrm{C}\left(\mathrm{CH}_{2} \mathrm{Cl}_{2}\right.$ /hexane); IR ( $\mathrm{KBr}$ disk): $v_{\max }=2955$ (w), $2213(\mathrm{~m}), 1701(\mathrm{~m}), 1603$ (s), $1488(\mathrm{~s}), 1438$ (s), 1418 (m), 1383 (m), $1336(\mathrm{~m}), 1295$ (w), 1241 (w), 1210 (s), 1174 (s), 1055 (w), 943 (w), 902 (w), $814(\mathrm{w}), 779(\mathrm{w}), 735(\mathrm{w}) \mathrm{cm}^{-1} ; \mathrm{UV} / \mathrm{Vis}\left(\mathrm{CH}_{2} \mathrm{Cl}_{2}\right): \lambda_{\max }(\log \varepsilon)=250$ (4.44), 265 sh (4.42), 303 (4.65), 346 sh (4.17), 391 sh (4.24), 474 (4.49) $\mathrm{nm}$; UV/Vis $\left(20 \% \mathrm{CH}_{2} \mathrm{Cl}_{2} /\right.$ hexane): $\lambda_{\max }(\log \varepsilon)=246$ (4.44), $265 \mathrm{sh}(4.43)$, 300 (4.38), $346 \mathrm{sh}$ (4.19), 389 (4.25), 459 (4.49) nm; ${ }^{1} \mathrm{H}$ NMR (500 MHz, $\left.\mathrm{CDCl}_{3}\right): \delta_{\mathrm{H}}=9.97(\mathrm{~d}, 1 \mathrm{H}, J=2.0 \mathrm{~Hz}, 4-\mathrm{H}), 8.51(\mathrm{~d}, 1 \mathrm{H}, J=10.0 \mathrm{~Hz}, 8-\mathrm{H})$, 8.31 (s, 1H, 2-H), 8.11 (d, 1H, $J=10.0 \mathrm{~Hz}, 6-\mathrm{H}), 7.93$ (dd, $1 \mathrm{H}, J=10.0$, $10.0 \mathrm{~Hz}, 7-\mathrm{H}), 7.92\left(\mathrm{~d}, 2 \mathrm{H}, J=9.0 \mathrm{~Hz}, 2^{\prime}, 6^{\prime}-\mathrm{H}\right), 6.78(\mathrm{~d}, 2 \mathrm{H}, J=9.0 \mathrm{~Hz}$, 3', ', $-\mathrm{H}$ ), 3.93 (s, $3 \mathrm{H}, \mathrm{CO}_{2} \mathrm{Me}$ ), 3.34 (sept, $1 \mathrm{H}, J=7.0 \mathrm{~Hz}, i \mathrm{Pr}$ ), 3.19 (s, $6 \mathrm{H}$, $\left.\mathrm{NMe}_{2}\right), 1.47$ (d, 6H, $\left.J=7.0 \mathrm{~Hz}, i \mathrm{Pr}\right) \mathrm{ppm} ;{ }^{13} \mathrm{C} \mathrm{NMR}\left(125 \mathrm{MHz}, \mathrm{CDCl}_{3}\right): \delta_{\mathrm{C}}$ $=165.54\left(\mathrm{CO}_{2} \mathrm{Me}\right), 164.57\left(\mathrm{C}=\mathrm{C}(\mathrm{CN})_{2}\right), 162.92\left(\mathrm{C}=\mathrm{C}(\mathrm{CN})_{2}\right), 156.34(\mathrm{C}-5)$, 154.36 (C-1'), 145.98 (C-8a), 142.93 (C-2), 142.09 (C-6), 141.87 (C-3a), 140.36 (C-4), 137.71 (C-8), 132.82 (C-2',6'), 131.95 (C-7), 120.07 (C-1), 119.18 (C-3), 118.94 (C-4'), $114.64(\mathrm{CN}), 114.07(\mathrm{CN}), 113.53(\mathrm{CN})$, $112.66(\mathrm{CN}), 112.24\left(\mathrm{C}-3^{\prime}, 5^{\prime}\right), 80.54\left(C(\mathrm{CN})_{2}\right), 74.85\left(C(\mathrm{CN})_{2}\right), 51.59$ $\left(\mathrm{CO}_{2} \mathrm{Me}\right), 40.18\left(\mathrm{NMe}_{2}\right), 39.43$ (iPr), 24.49 (iPr) ppm; HRMS (FAB) calcd for $\mathrm{C}_{31} \mathrm{H}_{25} \mathrm{~N}_{5} \mathrm{O}_{2}^{+}[\mathrm{M}]^{+}$499.2003, found 499.2006; Anal. Calcd for $\mathrm{C}_{31} \mathrm{H}_{25} \mathrm{~N}_{5} \mathrm{O}_{2}$ (499.56): C, 74.53; H, 5.04; N, 14.02. found: $\mathrm{C}, 74.39 ; \mathrm{H}, 4.88$; $\mathrm{N} 13.98$

Reaction of 10 with TCNQ: To a solution of $\mathbf{1 0}(186 \mathrm{mg}, 0.50 \mathrm{mmol})$ in ethyl acetate $(10 \mathrm{~mL})$ was added TCNQ $(123 \mathrm{mg}, 0.60 \mathrm{mmol})$. The resulting mixture was refluxed for $12 \mathrm{~h}$ under an Ar atmosphere. The solvent was removed under reduced pressure. The residue was purified by column chromatography on silica gel with $\mathrm{CH}_{2} \mathrm{Cl}_{2}$ /ethyl acetate (10:1) to give $\mathbf{1 5}(124 \mathrm{mg}, 43 \%)$ as dark green crystals and $\mathbf{1 6}(138 \mathrm{mg}, 48 \%)$ as dark green crystals, respectively.

Compound 15: M.p. $181.0-184.0{ }^{\circ} \mathrm{C}\left(\mathrm{CH}_{2} \mathrm{Cl}_{2} /\right.$ hexane); $\mathrm{IR}\left(\mathrm{KBr}\right.$ disk): $v_{\max }$ $=2960(\mathrm{w}), 2927(\mathrm{w}), 2207(\mathrm{~m}), 1698(\mathrm{~m}), 1602(\mathrm{~s}), 1540(\mathrm{w}), 1490(\mathrm{~m})$, $1438(\mathrm{~s}), 1420(\mathrm{~m}), 1379(\mathrm{~s}), 1330(\mathrm{~m}), 1288(\mathrm{w}), 1210(\mathrm{~s}), 1189(\mathrm{~s}), 1172$ (s), $1130(w), 1087(w), 1046(w), 998(w), 972(w), 943(w), 903(w), 860$ (w), 838 (w), 820 (w), $780(w), 700(w), 670(w) \mathrm{cm}^{-1}$; UV/Vis $\left(\mathrm{CH}_{2} \mathrm{Cl}_{2}\right)$ : $\lambda_{\max }(\log \varepsilon)=243$ (4.45), 298 (4.41), $377 \mathrm{sh}$ (4.72), 401 (4.92), $453 \mathrm{sh}$ (4.35), 631 (4.37) nm; UV/Vis ( $10 \% \mathrm{CH}_{2} \mathrm{Cl}_{2} /$ hexane): $\lambda_{\max }(\log \varepsilon)=242$ (4.45), 297 (4.41), 374 (4.75), 393 (4.97), 593 (4.36) nm; ${ }^{1} \mathrm{H}$ NMR (500 $\left.\mathrm{MHz}, \mathrm{CDCl}_{3}\right): \delta_{\mathrm{H}}=9.88(\mathrm{~d}, 1 \mathrm{H}, J=1.5 \mathrm{~Hz}, 4-\mathrm{H}), 8.38(\mathrm{~d}, 1 \mathrm{H}, J=10.0 \mathrm{~Hz}$, 8-H), 8.18 (s, 1H, 2-H), 7.97 (d, 1H, $J=10.0 \mathrm{~Hz}, 6-\mathrm{H}), 7.79$ (d, 2H, $J=9.5$ $\left.\mathrm{Hz}, 2^{\prime}, 6{ }^{\prime}-\mathrm{H}\right), 7.65$ (dd, 1H, $\left.J=10.0,10.0 \mathrm{~Hz}, 7-\mathrm{H}\right), 7.15-7.05$ (m, 4H, $\mathrm{H}_{\mathrm{DCN}}$ ), 6.67 (d, $\left.2 \mathrm{H}, \mathrm{J}=9.5 \mathrm{~Hz}, 3^{\prime}, 5^{\prime}-\mathrm{H}\right), 3.94$ (s, 3H, $\mathrm{CO}_{2} \mathrm{Me}$ ), 3.30 (sept, $1 \mathrm{H}, J=7.0 \mathrm{~Hz}, i \mathrm{Pr}$ ), 3.13 (s, 6H, NMe $), 1.45$ (d, 6H, J = 7.0 Hz, $i$ Pr) ppm; ${ }^{13} \mathrm{C}$ NMR $\left(125 \mathrm{MHz}, \mathrm{CDCl}_{3}\right): \delta_{\mathrm{C}}=169.29\left(\mathrm{C}_{\mathrm{DCNQ}}\right), 164.79\left(\mathrm{CO}_{2} \mathrm{Me}\right)$, $154.58(\mathrm{C}-5), 154.27\left(C=\mathrm{C}(\mathrm{CN})_{2}\right), 153.87\left(C=\mathrm{C}(\mathrm{CN})_{2}\right), 148.25(\mathrm{C}-1$ ')
144.96 (C-8a), 143.73 (C-3a), 143.67 (C-2), 141.43 (C-6), 139.99 (C-4), 136.69 (C-8), $136.29\left(\mathrm{C}_{\mathrm{DCNQ}}\right), 134.55\left(\mathrm{C}_{\mathrm{DCNQ}}\right), 132.79\left(\mathrm{C}-2^{\prime}, 6^{\prime}\right), 132.57$, 130.94 (C-7), $125.09\left(\mathrm{C}_{\mathrm{DCNQ}}\right), 124.95(\mathrm{C}-1), 124.60\left(\mathrm{C}_{\mathrm{DCNQ}}\right), 121.54\left(\mathrm{C}-4^{\prime}\right)$, $118.79(\mathrm{C}-3), 115.26(\mathrm{CN}), 114.48(\mathrm{CN}), 114.39(\mathrm{CN}), 114.26(\mathrm{CN})$, 111.93 (C-3',5'), $76.38\left(C(\mathrm{CN})_{2}\right), 73.01\left(C(\mathrm{CN})_{2}\right), 51.51\left(\mathrm{CO}_{2} \mathrm{Me}\right), 40.10$ $\left(\mathrm{NMe}_{2}\right.$ ), 39.34 (iPr), 24.49 (iPr) ppm; HRMS (FAB) calcd for $\mathrm{C}_{37} \mathrm{H}_{29} \mathrm{~N}_{5} \mathrm{O}_{2}{ }^{+}$ $[\mathrm{M}]^{+}$575.2316, found 575.2340; Anal. Calcd for $\mathrm{C}_{37} \mathrm{H}_{29} \mathrm{~N}_{5} \mathrm{O}_{2}$ (575.66): C, 77.20; H, 5.08; N, 12.17. found: C, 77.08; H, 5.19; N 12.13 .

Compound 16: M.p. $183.0-187.0{ }^{\circ} \mathrm{C}$ decomp. $\left(\mathrm{CH}_{2} \mathrm{Cl}_{2} /\right.$ hexane); IR ( $\mathrm{KBr}$ disk): $v_{\max }=2956(\mathrm{w}), 2202(\mathrm{~m}), 1697(\mathrm{~m}), 1581(\mathrm{~s}), 1485(\mathrm{w}), 1440(\mathrm{~m})$, 1417 (m), 1367 (s), 1347 (s), 1325 (w), 1273 (w), 1231 (w), 1221 (w), 1169 (s), $1130(w), 1048(w), 998(w), 942(w), 908(w), 838(w), 818(w), 793$ (w), $746(w), 725(w), 674(w) \mathrm{cm}^{-1}$; UV/Vis $\left(\mathrm{CH}_{2} \mathrm{Cl}_{2}\right): \lambda_{\max }(\log \varepsilon)=238$ (4.46), 262 (4.42), 301 (4.45), 338 (4.38), 415 (4.43), 462 sh (4.30), 689 (4.52) nm; UV/Vis $\left(10 \% \mathrm{CH}_{2} \mathrm{Cl}_{2} /\right.$ hexane): $\lambda_{\max }(\log \varepsilon)=262(4.43), 301$ (4.43), 334 (4.39), 409 (4.44), 619 (4.48) nm; ${ }^{1} \mathrm{H}$ NMR (500 MHz, $\mathrm{CDCl}_{3}$ ): $\delta_{\mathrm{H}}=9.93(\mathrm{~d}, 1 \mathrm{H}, J=1.5 \mathrm{~Hz}, 4-\mathrm{H}), 8.57(\mathrm{~s}, 1 \mathrm{H}, 2-\mathrm{H}), 8.45(\mathrm{~d}, 1 \mathrm{H}, J=10.0$ $\mathrm{Hz}, 8-\mathrm{H}), 8.02$ (d, $1 \mathrm{H}, J=10.0 \mathrm{~Hz}, 6-\mathrm{H}), 7.76$ (dd, $1 \mathrm{H}, J=10.0,10.0 \mathrm{~Hz}$, $7-\mathrm{H}), 7.51\left(\mathrm{dd}, 1 \mathrm{H}, J=9.5,2.0 \mathrm{~Hz}, \mathrm{H}_{\mathrm{DCNQ}}\right), 7.36(\mathrm{~d}, 2 \mathrm{H}, J=9.0 \mathrm{~Hz}$, 2', 6'-H), $7.24\left(\mathrm{dd}, 1 \mathrm{H}, J=9.5,2.0 \mathrm{~Hz}, \mathrm{H}_{\mathrm{DCNQ}}\right), 7.02(\mathrm{dd}, 1 \mathrm{H}, J=9.5,2.0$ $\left.\mathrm{Hz}, \mathrm{H}_{\mathrm{DCNQ}}\right), 6.98\left(\mathrm{dd}, 1 \mathrm{H}, J=9.5,2.0 \mathrm{~Hz}, \mathrm{H}_{\mathrm{DCNQ}}\right), 6.70(\mathrm{~d}, 2 \mathrm{H}, J=9.0 \mathrm{~Hz}$, 3',5'-H), 3.93 (s, 3H, CO ${ }_{2} \mathrm{Me}$ ), 3.30 (sept, $1 \mathrm{H}, J=7.0 \mathrm{~Hz}, i \mathrm{Pr}$ ), 3.12 (s, $6 \mathrm{H}$, $\mathrm{NMe}_{2}$ ), 1.44 (d, $\left.6 \mathrm{H}, J=7.0 \mathrm{~Hz}, i \mathrm{Pr}\right) \mathrm{ppm} ;{ }^{13} \mathrm{C} \mathrm{NMR}\left(125 \mathrm{MHz}, \mathrm{CDCl}_{3}\right): \delta_{\mathrm{C}}$ $=166.28,164.63\left(\mathrm{CO}_{2} \mathrm{Me}\right), 155.62,154.09,153.97,152.86,145.55,143.25$, $141.67,141.57,140.20,136.43,136.07,134.99,134.45,132.78,132.62$, $131.22,125.14,125.02,124.49,122.84,118.47,114.95,114.82(\mathrm{CN})$, $113.53(\mathrm{CN}), 112.47(\mathrm{CN}), 111.91(\mathrm{CN}), 82.35\left(C(\mathrm{CN})_{2}\right), 70.89\left(C(\mathrm{CN})_{2}\right)$, $51.62\left(\mathrm{CO}_{2} \mathrm{Me}\right), 40.18\left(\mathrm{NMe}_{2}\right), 39.33$ (iPr), 24.46 (iPr) ppm; HRMS (FAB) calcd for $\mathrm{C}_{37} \mathrm{H}_{29} \mathrm{~N}_{5} \mathrm{O}_{2}^{+}[\mathrm{M}]^{+}$575.2316, found 575.2313; Anal. Calcd for $\mathrm{C}_{37} \mathrm{H}_{29} \mathrm{~N}_{5} \mathrm{O}_{2}$ (575.66): C, 77.20; H, 5.08; N, 12.17. found: C, 77.11; H, 5.16; $\mathrm{N} 12.15$.

Compound 17: To a solution of $\mathbf{1 1}(201 \mathrm{mg}, 0.30 \mathrm{mmol})$ in ethyl acetate $(10 \mathrm{~mL})$ was added TCNE $(102 \mathrm{mg}, 0.80 \mathrm{mmol})$. The resulting mixture was refluxed for $6 \mathrm{~h}$ under an $\mathrm{Ar}$ atmosphere. The solvent was removed under reduced pressure. The residue was purified by column chromatography on silica gel with $\mathrm{CH}_{2} \mathrm{Cl}_{2} /$ ethyl acetate (20:1) to give 17 (272 mg, 98\%) as red crystals. M.p. $170.0-172.0{ }^{\circ} \mathrm{C}\left(\mathrm{CH}_{2} \mathrm{Cl}_{2} /\right.$ hexane); IR ( $\mathrm{KBr}$ disk): $v_{\max }=2953$ (w), $2224(\mathrm{~m}), 1700(\mathrm{~m}), 1588(\mathrm{~s}), 1489(\mathrm{~s}), 1439(\mathrm{~m}), 1418(\mathrm{~m}), 1383(\mathrm{~m})$, $1284(w), 1240(w), 1212(w), 1179(\mathrm{~s}), 1093(w), 1041(w), 902(w), 817$ (w), 777 (w), 729 (w), $664(\mathrm{w}) \mathrm{cm}^{-1} ; \mathrm{UV} / \mathrm{Vis}\left(\mathrm{CH}_{2} \mathrm{Cl}_{2}\right): \lambda_{\max }(\log \varepsilon)=262$ (4.80), 300 (4.74), $340 \mathrm{sh}$ (4.57), $389 \mathrm{sh}$ (4.48), 489 (4.81) nm; UV/Vis (20\% $\mathrm{CH}_{2} \mathrm{Cl}_{2} /$ hexane): $\lambda_{\max }(\log \varepsilon)=246$ (4.44), 262 (4.43), 300 (4.38), 341 sh (4.21), 389 (4.25), 459 (4.49) nm; ${ }^{1} \mathrm{H}$ NMR (500 MHz, $\left.\mathrm{CDCl}_{3}\right): \delta_{\mathrm{H}}=$ 10.00 (d, $2 \mathrm{H}, J=2.0 \mathrm{~Hz}, 4-\mathrm{H}), 8.49$ (d, $2 \mathrm{H}, \mathrm{J}=10.0 \mathrm{~Hz}, 8-\mathrm{H}), 8.30$ (s, $2 \mathrm{H}$, 2-H), 8.16 (d, $2 \mathrm{H}, J=10.0 \mathrm{~Hz}, 6-\mathrm{H}), 7.99$ (d, $2 \mathrm{H}, J=10.0 \mathrm{~Hz}, 7-\mathrm{H}), 7.90$ (d, $\left.4 \mathrm{H}, J=8.5 \mathrm{~Hz}, 2^{\prime}, 6^{\prime}-\mathrm{H}\right), 7.32$ (d, 4H, $\left.J=8.5 \mathrm{~Hz}, 3^{\prime}, 5^{\prime}-\mathrm{H}\right), 7.29$ (s, 1H, NH), 3.95 (s, $6 \mathrm{H}, \mathrm{CO}_{2} \mathrm{Me}$ ), 3.35 (sept, $2 \mathrm{H}, J=7.0 \mathrm{~Hz}, i \mathrm{Pr}$ ), 1.47 (d, $12 \mathrm{H}, J=7.0$ $\mathrm{Hz}, i \mathrm{Pr}) \mathrm{ppm} ;{ }^{13} \mathrm{C}$ NMR $\left(125 \mathrm{MHz}, \mathrm{CDCl}_{3}\right): \delta_{\mathrm{C}}=167.05\left(\mathrm{C}-1^{\prime}\right), 164.41$ $\left(\mathrm{CO}_{2} \mathrm{Me}\right), 161.16\left(\mathrm{C}=\mathrm{C}(\mathrm{CN})_{2}\right), 157.13(\mathrm{C}-5), 146.25\left(\mathrm{C}=\mathrm{C}(\mathrm{CN})_{2}\right), 146.21$ (C-8a), 142.61 (C-2 or 6), 142.58 (C-2 or 6), 142.00 (C-3a), 140.77 (C-4), 137.68 (C-8), 132.44 (C-2',6'), 132.38 (C-7), 125.86 (C-4'), 119.69 (C-1), $119.51(\mathrm{C}-3), 118.52\left(\mathrm{C}-3^{\prime}, 5^{\prime}\right), 113.75(\mathrm{CN}), 112.96(\mathrm{CN}), 112.66(\mathrm{CN})$, $111.86(\mathrm{CN}), 83.19\left(C(\mathrm{CN})_{2}\right), 80.33\left(C(\mathrm{CN})_{2}\right), 51.76\left(\mathrm{CO}_{2} \mathrm{Me}\right), 39.51(i \mathrm{Pr})$, 24.49 (iPr) ppm; HRMS (FAB) calcd for $\mathrm{C}_{58} \mathrm{H}_{39} \mathrm{~N}_{9} \mathrm{O}_{4}{ }^{+}[\mathrm{M}]^{+}$925.3120, found 925.3139; Anal. Calcd for $\mathrm{C}_{58} \mathrm{H}_{39} \mathrm{~N}_{9} \mathrm{O}_{4}$ (925.99): $\mathrm{C}, 75.23 ; \mathrm{H}, 4.25 ; \mathrm{N}$, 13.61. found: $\mathrm{C}, 75.10 ; \mathrm{H}, 4.38 ; \mathrm{N} 13.57$.

Compound 18: To a solution of $\mathbf{1 1}(201 \mathrm{mg}, 0.30 \mathrm{mmol})$ in ethyl acetate $(15 \mathrm{~mL})$ was added TCNQ $(204 \mathrm{mg}, 1.00 \mathrm{mmol})$. The resulting mixture was refluxed for $12 \mathrm{~h}$ under an $\mathrm{Ar}$ atmosphere. The solvent was removed under reduced pressure. The residue was purified by column chromatography on 
silica gel with $\mathrm{CH}_{2} \mathrm{Cl}_{2} /$ ethyl acetate (10:1) to give $\mathbf{1 8}$ (294 mg, 91\%) as dark green crystals. M.p. $246.0-248.0^{\circ} \mathrm{C}\left(\mathrm{CH}_{2} \mathrm{Cl}_{2} /\right.$ hexane); $\mathrm{IR}$ ( $\mathrm{KBr}$ disk): $v_{\max }=$ 2961 (w), 2208 (m), $1698(\mathrm{~m}), 1588$ (s), 1505 (s), 1439 (s), 1420 (m), 1398 (m), $1381(\mathrm{~m}), 1350(\mathrm{~m}), 1317(\mathrm{~m}), 1279(\mathrm{~m}), 1214(\mathrm{~s}), 1189(\mathrm{~s}), 1128(\mathrm{w})$, $1085(w), 1046(w), 974(w), 904(w), 836(w), 809(w), 778(w), 757(w)$, $744(\mathrm{w}), 727(\mathrm{w}), 655(\mathrm{w}) \mathrm{cm}^{-1}$; UV/Vis $\left(\mathrm{CH}_{2} \mathrm{Cl}_{2}\right): \lambda_{\max }(\log \varepsilon)=242(4.79)$, 297 (4.80), 421 (4.76), 628 (4.71) nm; UV/Vis ( $50 \% \mathrm{CH}_{2} \mathrm{Cl}_{2} /$ hexane): $\lambda_{\max }$ $(\log \varepsilon)=242(4.80), 297$ (4.81), 417 (4.77), $617(4.71) \mathrm{nm} ;{ }^{1} \mathrm{H}$ NMR $(500$ $\left.\mathrm{MHz}, \mathrm{CDCl}_{3}\right): \delta_{\mathrm{H}}=9.87(\mathrm{~d}, 2 \mathrm{H}, J=2.0 \mathrm{~Hz}, 4-\mathrm{H}), 8.31(\mathrm{~d}, 2 \mathrm{H}, J=10.0 \mathrm{~Hz}$, $8-\mathrm{H}), 8.16$ (s, 2H, 2-H), 8.00 (d, 2H, $J=10.0 \mathrm{~Hz}, 6-\mathrm{H}), 7.75$ (d, 4H, $J=9.0$ $\left.\mathrm{Hz}, 2^{\prime}, 6{ }^{\prime}-\mathrm{H}\right), 7.67$ (dd, 2H, $\left.J=10.0,10.0 \mathrm{~Hz}, 7-\mathrm{H}\right), 7.18-7.15$ (m, 8H, $\mathrm{H}_{\mathrm{DCNQ}}$ and $\left.3^{\prime}, 5^{\prime}-\mathrm{H}\right), 7.12-7.04\left(\mathrm{~m}, 3 \mathrm{H}, \mathrm{H}_{\mathrm{DCNQ}}\right.$ and $\left.\mathrm{NH}\right), 3.94(\mathrm{~s}, 6 \mathrm{H}$, $\mathrm{CO}_{2} \mathrm{Me}$ ), 3.30 (sept, $\left.2 \mathrm{H}, J=7.0 \mathrm{~Hz}, i \operatorname{Pr}\right), 1.45$ (d, $12 \mathrm{H}, J=7.0 \mathrm{~Hz}, i \operatorname{Pr}$ ) ppm; ${ }^{13} \mathrm{C}$ NMR $\left(125 \mathrm{MHz}, \mathrm{CDCl}_{3}\right): \delta_{\mathrm{C}}=170.38\left(\mathrm{C}_{\mathrm{DCNQ}}\right), 164.65\left(\mathrm{CO}_{2} \mathrm{Me}\right)$, $155.01(\mathrm{C}-5), 153.86\left(C=\mathrm{C}(\mathrm{CN})_{2}\right), 146.21\left(C=\mathrm{C}(\mathrm{CN})_{2}\right), 145.71\left(\mathrm{C}-1{ }^{\prime}\right)$, 144.87 (C-8a), 143.78 (C-3a), 143.37 (C-2), 141.73 (C-6), 140.22 (C-4), 136.37 (C-8 or $\left.\mathrm{C}_{\mathrm{DCNQ}}\right), 136.27$ (C-8 or $\left.\mathrm{C}_{\mathrm{DCNQ}}\right), 134.04\left(\mathrm{C}_{\mathrm{DCNQ}}\right), 133.24$, 132.18 (C-2',6'), 131.14 (C-7), 128.13 (C-4'), 125.57 ( $\left.\mathrm{C}_{\mathrm{DCNQ}}\right), 125.10$ $\left(\mathrm{C}_{\mathrm{DCNQ}}\right), 124.47$ (C-1), $119.02(\mathrm{C}-3), 118.13\left(\mathrm{C}^{\prime} 3^{\prime}, 5^{\prime}\right), 114.20(\mathrm{CN} \times 2)$, $113.80(\mathrm{CN}), 112.81(\mathrm{CN}), 83.35\left(C(\mathrm{CN})_{2}\right), 74.07\left(C(\mathrm{CN})_{2}\right), \quad 51.63$ $\left(\mathrm{CO}_{2} \mathrm{Me}\right), \quad 39.35$ (iPr), 24.46 (iPr) ppm; HRMS (FAB) calcd for $\mathrm{C}_{70} \mathrm{H}_{47} \mathrm{~N}_{9} \mathrm{O}_{4}^{+}[\mathrm{M}]^{+}$1077.3746, found 1077.3776; Anal. Calcd for $\mathrm{C}_{70} \mathrm{H}_{47} \mathrm{~N}_{9} \mathrm{O}_{4} \cdot 2 / 5 \mathrm{H}_{2} \mathrm{O}$ (1078.18): C, 77.46; H, 4.44; N, 11.61. found: $\mathrm{C}$, $77.52 ; \mathrm{H}, 4.50 ; \mathrm{N} 11.60$.

Compound 19: To a solution of $\mathbf{1 2}(200 \mathrm{mg}, 0.30 \mathrm{mmol})$ in ethyl acetate $(10 \mathrm{~mL})$ was added TCNE $(102 \mathrm{mg}, 0.80 \mathrm{mmol})$. The resulting mixture was refluxed for $6 \mathrm{~h}$ under an Ar atmosphere. The solvent was removed under reduced pressure. The residue was purified by column chromatography on silica gel with $\mathrm{CH} 2 \mathrm{Cl} 2 /$ ethyl acetate (20:1) to give 19 (255 mg, 92\%) as red crystals. M.p. $217.0-220.0{ }^{\circ} \mathrm{C}$ decomp. $\left(\mathrm{CH}_{2} \mathrm{Cl}_{2} /\right.$ hexane); $\mathrm{IR}$ ( $\mathrm{KBr}$ disk): $v_{\max }=2957(\mathrm{w}), 2875(\mathrm{w}), 2221(\mathrm{~m}), 1700(\mathrm{~m}), 1628(\mathrm{w}), 1600(\mathrm{~m}), 1496$ (s), $1442(\mathrm{~s}), 1418(\mathrm{~s}), 1363(\mathrm{~m}), 1313(\mathrm{w}), 1280(\mathrm{w}), 1255(\mathrm{~m}), 1236(\mathrm{~s})$, 1213 (s), 1179 (s), 1143 (s), 1087 (w), 1041 (w), 904 (w), $812(\mathrm{~m}), 777$ (m), $729(\mathrm{w}), 695(\mathrm{w}), 678(\mathrm{w}) \mathrm{cm}^{-1}$; UV/Vis $\left(\mathrm{CH}_{2} \mathrm{Cl}_{2}\right): \lambda_{\max }(\log \varepsilon)=233(4.78)$, 266 (4.77), 299 (4.80), $347 \mathrm{sh}$ (4.55), 403 (4.50), 456 (4.58) nm; UV/Vis (20\% $\mathrm{CH}_{2} \mathrm{Cl}_{2} /$ hexane): $\lambda_{\max }(\log \varepsilon)=233$ (4.78), 263 (4.78), 299 (4.80), 347 sh (4.55), 402 (4.53), $449(4.55) \mathrm{nm} ;{ }^{1} \mathrm{H}$ NMR (500 MHz, $\left.\mathrm{CDCl}_{3}\right): \delta_{\mathrm{H}}=$ $9.95(\mathrm{~d}, 2 \mathrm{H}, J=2.0 \mathrm{~Hz}, 4-\mathrm{H}), 9.50$ (s, $1 \mathrm{H}, \mathrm{NH}), 8.61$ (d, $2 \mathrm{H}, J=1.5 \mathrm{~Hz}$, $\left.4^{\prime}, 5^{\prime}-\mathrm{H}\right), 8.55$ (d, 2H, $\left.J=10.0 \mathrm{~Hz}, 8-\mathrm{H}\right), 8.27$ (s, 2H, 2-H), 8.14 (d, 2H, $J=$ $10.0 \mathrm{~Hz}, 6-\mathrm{H}), 8.00$ (dd, $2 \mathrm{H}, J=10.0,10.0 \mathrm{~Hz}, 7-\mathrm{H}), 7.84$ (dd, $2 \mathrm{H}, J=9.0$, $\left.1.5 \mathrm{~Hz}, 2^{\prime}, 7^{\prime}-\mathrm{H}\right), 7.44$ (d, $\left.2 \mathrm{H}, J=9.0 \mathrm{~Hz}, 1^{\prime}, 8^{\prime}-\mathrm{H}\right), 3.89$ (s, 6H, $\left.\mathrm{CO}_{2} \mathrm{Me}\right)$, 3.33 (sept, $2 \mathrm{H}, J=7.0 \mathrm{~Hz}, i \operatorname{Pr}$ ), $1.44\left(\mathrm{~d}, 12 \mathrm{H}, J=7.0 \mathrm{~Hz}, i \operatorname{Pr}\right.$ ) ppm; ${ }^{13} \mathrm{C}$ NMR (125 MHz, $\left.\mathrm{CDCl}_{3}\right): \delta_{\mathrm{C}}=168.69\left(\mathrm{C}-3^{\prime}, 6^{\prime}\right), 164.43\left(\mathrm{CO}_{2} \mathrm{Me}\right), 161.01$ $\left(C=\mathrm{C}(\mathrm{CN})_{2}\right), 157.03$ (C-5), 146.14 (C-8a), 143.39 (C-4a',4b'), 142.59 (C-2 or 6), 142.47 (C-2 or 6), 141.96 (C-3a), 140.72 (C-4), 137.71 (C-8), 132.47 (C-7), $129.42\left(\mathrm{C}-2^{\prime}, 7^{\prime}\right), 124.70\left(\mathrm{C}=\mathrm{C}(\mathrm{CN})_{2}\right), 123.35\left(\mathrm{C}-8 \mathrm{a}^{\prime}, 9 \mathrm{a}^{\prime}\right), 123.22$ (C-4',5'), 119.49 (C-1 or 3), 119.35 (C-1 or 3), $113.67(\mathrm{CN}), 113.46(\mathrm{CN})$, $113.16(\mathrm{CN}), 112.99\left(\mathrm{C}^{\prime} 1^{\prime}, 8^{\prime}\right), 111.83(\mathrm{CN}), 84.27\left(C(\mathrm{CN})_{2}\right), 81.08$ $\left(C(\mathrm{CN})_{2}\right), 51.74\left(\mathrm{CO}_{2} \mathrm{Me}\right), 39.49(i \mathrm{Pr}), 24.47$ (iPr) ppm; HRMS (FAB) calcd for $\mathrm{C}_{58} \mathrm{H}_{37} \mathrm{~N}_{9} \mathrm{O}_{4}{ }^{+}[\mathrm{M}]^{+}$923.2964, found 923.2978; Anal. Calcd for $\mathrm{C}_{58} \mathrm{H}_{37} \mathrm{~N}_{9} \mathrm{O}_{4}$ (923.97): C, 75.39; H, 4.04; N, 13.64. found: C, 75.18; H, 4.15; $\mathrm{N} 13.58$.

Compound 20: To a solution of $\mathbf{1 2}(200 \mathrm{mg}, 0.30 \mathrm{mmol})$ in ethyl acetate $(15 \mathrm{~mL})$ was added TCNE (204 mg, $1.00 \mathrm{mmol})$. The resulting mixture was refluxed for $12 \mathrm{~h}$ under an Ar atmosphere. The solvent was removed under reduced pressure. The residue was purified by column chromatography on silica gel with $\mathrm{CH}_{2} \mathrm{Cl}_{2} /$ ethyl acetate (10:1) to give 20 (271 mg, 84\%) as dark green crystals. M.p. $267.0-273.0^{\circ} \mathrm{C}\left(\mathrm{CH}_{2} \mathrm{Cl}_{2} /\right.$ hexane); $\mathrm{IR}$ ( $\mathrm{KBr}$ disk): $v_{\max }=$ 2957 (w), 2208 (m), 1698 (m), 1599 (m), 1506 (s), 1442 (s), 1419 (s), 1397 (s), $1380(\mathrm{~m}), 1358(\mathrm{~m}), 1309(\mathrm{w}), 1270(\mathrm{w}), 1213(\mathrm{~s}), 1191(\mathrm{~s}), 1141(\mathrm{w})$, $1087(w), 1045(w), 930(w), 905(w), 838(w), 811(w), 776(w), 729(w)$, $664(\mathrm{w}), 655(\mathrm{w}) \mathrm{cm}^{-1} ; \mathrm{UV} / \mathrm{Vis}\left(\mathrm{CH}_{2} \mathrm{Cl}_{2}\right): \lambda_{\max }(\log \varepsilon)=241$ (4.88), 297 (4.91), 386 (4.73), 637 (4.70) nm; UV/Vis $\left(50 \% \mathrm{CH}_{2} \mathrm{Cl}_{2} /\right.$ hexane): $\lambda_{\max }(\log$ $\varepsilon)=240$ (4.87), 297 (4.91), 382 (4.72), $626(4.69) \mathrm{nm} ; 1 \mathrm{H} \mathrm{NMR} \mathrm{(500} \mathrm{MHz,}$ $\left.\mathrm{CDCl}_{3}\right): \delta_{\mathrm{H}}=9.86(\mathrm{~d}, 2 \mathrm{H}, J=2.0 \mathrm{~Hz}, 4-\mathrm{H}), 9.16(\mathrm{~s}, 1 \mathrm{H}, \mathrm{NH}), 8.57(\mathrm{~d}, 2 \mathrm{H}, J$ $\left.=1.5 \mathrm{~Hz}, 4^{\prime}, 5^{\prime}-\mathrm{H}\right), 8.35(\mathrm{~d}, 2 \mathrm{H}, J=10.0 \mathrm{~Hz}, 8-\mathrm{H}), 8.23(\mathrm{~s}, 2 \mathrm{H}, 2-\mathrm{H}), 7.98$ (d, $2 \mathrm{H}, J=10.0 \mathrm{~Hz}, 6-\mathrm{H}), 7.74$ (dd, $\left.2 \mathrm{H}, J=8.5,1.5 \mathrm{~Hz}, 2^{\prime}, 7^{\prime}-\mathrm{H}\right), 7.68$ (dd, $2 \mathrm{H}, J=10.0,10.0 \mathrm{~Hz}, 7-\mathrm{H}), 7.48$ (s, $\left.2 \mathrm{H}, J=8.5 \mathrm{~Hz}, 1^{\prime}, 8^{\prime}-\mathrm{H}\right), 7.18-7.13$ (m, $4 \mathrm{H}, \mathrm{H}_{\mathrm{DCNQ}}$ ), 7.10 (br s, 4H, $\mathrm{H}_{\mathrm{DCNQ}}$ ), 3.93 (s, $6 \mathrm{H}, \mathrm{CO}_{2} \mathrm{Me}$ ), 3.28 (sept, $2 \mathrm{H}, J$ $=7.0 \mathrm{~Hz}, i \operatorname{Pr}), 1.44(\mathrm{~d}, 12 \mathrm{H}, J=7.0 \mathrm{~Hz}, i \mathrm{Pr}) \mathrm{ppm} ;{ }^{13} \mathrm{C} \mathrm{NMR}(125 \mathrm{MHz}$, $\left.\mathrm{CDCl}_{3}\right): \delta_{\mathrm{C}}=172.23\left(\mathrm{C}_{\mathrm{DCNQ}}\right), 164.68\left(\mathrm{CO}_{2} \mathrm{Me}\right), 155.04(\mathrm{C}-5), 153.75$ $\left(C=\mathrm{C}(\mathrm{CN})_{2}\right), 146.30\left(\mathrm{C}_{\mathrm{DCNQ}}\right), 144.85(\mathrm{C}-8 \mathrm{a}), 143.86\left(C=\mathrm{C}(\mathrm{CN})_{2}\right), 143.52$ (C-2), 142.91 (C-3a), 141.78 (C-6), 140.22 (C-4), 136.35 (C-8 and $\mathrm{C}_{\mathrm{DCNQ}}$ ), 134.09, 133.83 ( $\left.\mathrm{C}_{\mathrm{DCNQ}}\right), 131.29$ (C-7), 129.33 (C-2',7'), 127.73, 125.72, $125.19\left(\mathrm{C}_{\mathrm{DCNQ}}\right), 124.69\left(\mathrm{C}_{\mathrm{DCNQ}}\right), 123.54(\mathrm{C}-1), 123.18\left(\mathrm{C}-4^{\prime}, 5^{\prime}\right), 119.04$ $(\mathrm{C}-3), 114.15(\mathrm{CN} \times 2), 113.97\left(\mathrm{C}-1^{\prime}, 8^{\prime}\right.$ and $\left.\mathrm{CN}\right), 112.69(\mathrm{CN}), 84.87$ $\left(C(\mathrm{CN})_{2}\right), 74.30\left(C(\mathrm{CN})_{2}\right), 51.66\left(\mathrm{CO}_{2} \mathrm{Me}\right), 39.36(i \mathrm{Pr}), 24.46(i \mathrm{Pr}) \mathrm{ppm}$; HRMS (FAB) calcd for $\mathrm{C}_{70} \mathrm{H}_{45} \mathrm{~N}_{9} \mathrm{O}_{4}^{+}[\mathrm{M}]^{+}$1075.3590, found 1075.3605; Anal. Calcd for $\mathrm{C}_{70} \mathrm{H}_{45} \mathrm{~N}_{9} \mathrm{O}_{4} \cdot 3 / 4 \mathrm{H}_{2} \mathrm{O}$ (1076.16): C, 77.16; H, 4.30; N, 11.57 . found: $\mathrm{C}, 77.26 ; \mathrm{H}, 4.41 ; \mathrm{N} 11.56$.

Compound 21: To a solution of $\mathbf{1 3}(199 \mathrm{mg}, 0.20 \mathrm{mmol})$ in ethyl acetate $(10 \mathrm{~mL})$ was added TCNE $(128 \mathrm{mg}, 1.00 \mathrm{mmol})$. The resulting mixture was refluxed for $6 \mathrm{~h}$ under an $\mathrm{Ar}$ atmosphere. The solvent was removed under reduced pressure. The residue was purified by column chromatography on silica gel with $\mathrm{CH}_{2} \mathrm{Cl}_{2} /$ ethyl acetate (10:1) to give 21 (249 mg, 90\%) as red crystals. M.p. $201.0-205.0{ }^{\circ} \mathrm{C}$ decomp. $\left(\mathrm{CH}_{2} \mathrm{Cl}_{2} /\right.$ hexane); $\mathrm{IR}$ ( $\mathrm{KBr}$ disk): $v_{\max }=2962(\mathrm{w}), 2879(\mathrm{w}), 2221(\mathrm{~m}), 1698(\mathrm{~m}), 1590(\mathrm{~m}), 1496(\mathrm{~s}), 1441$ (m), $1418(\mathrm{~m}), 1363(\mathrm{w}), 1327(\mathrm{w}), 1291(\mathrm{~m}), 1240(\mathrm{w}), 1212(\mathrm{~m}), 1181(\mathrm{~s})$, $1134(w), 1086(w), 1053(w), 906(w), 812(w), 778(m), 732(m), 712(w)$, $668(\mathrm{w}) \mathrm{cm}^{-1}$; UV/Vis $\left(\mathrm{CH}_{2} \mathrm{Cl}_{2}\right): \lambda_{\max }(\log \varepsilon)=264(4.95), 300$ (4.92), 338 sh (4.73), 404 (4.66), 503 (4.86) nm; UV/Vis $\left(20 \% \mathrm{CH}_{2} \mathrm{Cl}_{2} /\right.$ hexane): $\lambda_{\max }$ $(\log \varepsilon)=264$ (4.94), 298 (4.91), $338 \mathrm{sh}(4.71), 403(4.64), 488$ (4.84) nm; ${ }^{1} \mathrm{H}$ NMR $\left(500 \mathrm{MHz}, \mathrm{CDCl}_{3}\right): \delta_{\mathrm{H}}=10.01(\mathrm{~d}, 3 \mathrm{H}, J=2.0 \mathrm{~Hz}, 4-\mathrm{H}), 8.47$ (d, $3 \mathrm{H}, J=10.0 \mathrm{~Hz}, 8-\mathrm{H}), 8.29$ (s, 3H, 2-H), 8.17 (d, 3H, $J=10.0 \mathrm{~Hz}, 6-\mathrm{H})$, 8.00 (dd, 3H, $J=10.0,10.0 \mathrm{~Hz}, 7-\mathrm{H}), 7.87$ (d, 6H, $\left.J=9.0 \mathrm{~Hz}, 2^{\prime}, 6^{\prime}-\mathrm{H}\right)$, 7.39 (d, 6H, $\left.J=9.0 \mathrm{~Hz}, 3^{\prime}, 5^{\prime}-\mathrm{H}\right), 3.97$ (s, 9H, $\mathrm{CO}_{2} \mathrm{Me}$ ), 3.36 (sept, 3H, $J=$ $7.0 \mathrm{~Hz}, i \mathrm{Pr}), 1.48(\mathrm{~d}, 18 \mathrm{H}, J=7.0 \mathrm{~Hz}, i \mathrm{Pr}) \mathrm{ppm} ;{ }^{13} \mathrm{C} \mathrm{NMR}(125 \mathrm{MHz}$, $\left.\mathrm{CDCl}_{3}\right): \delta_{\mathrm{C}}=167.07\left(C=\mathrm{C}(\mathrm{CN})_{2}\right), 164.31\left(\mathrm{CO}_{2} \mathrm{Me}\right), 160.38\left(C=\mathrm{C}(\mathrm{CN})_{2}\right)$, 157.31 (C-5), 149.80 (C-1'), 146.24 (C-8a), 142.72 (C-6), 142.45 (C-2), 141.98 (C-3a), 140.91 (C-4), 137.63 (C-8), 132.45 (C-7), 132.16 (C-2',6'), 128.80 (C-4'), 125.26 (C-3',5'), 119.70 (C-1), 119.50 (C-3), $113.61(\mathrm{CN})$, $112.56(\mathrm{CN}), 112.37(\mathrm{CN}), 111.33(\mathrm{CN}), 86.17\left(C(\mathrm{CN})_{2}\right), 80.53\left(C(\mathrm{CN})_{2}\right)$, $51.81\left(\mathrm{CO}_{2} \mathrm{Me}\right), 39.53(i \mathrm{Pr}), 24.48(i \mathrm{Pr}) \mathrm{ppm}$; HRMS (FAB) calcd for $\mathrm{C}_{87} \mathrm{H}_{57} \mathrm{~N}_{13} \mathrm{O}_{6}^{+}[\mathrm{M}]^{+}$1379.4550, found 1379.4575; Anal. Calcd for $\mathrm{C}_{87} \mathrm{H}_{57} \mathrm{~N}_{13} \mathrm{O}_{6} \cdot 3 / 4 \mathrm{H}_{2} \mathrm{O}$ (1380.47): C, 74.96; $\mathrm{H}, 4.23 ; \mathrm{N}, 13.06$. found: $\mathrm{C}$, $75.11 ; \mathrm{H}, 4.41 ; \mathrm{N}, 13.05$.

Compound 22: To a solution of $\mathbf{1 3}(199 \mathrm{mg}, 0.20 \mathrm{mmol})$ in ethyl acetate $(20 \mathrm{~mL})$ was added TCNQ $(204 \mathrm{mg}, 1.00 \mathrm{mmol})$. The resulting mixture was refluxed for $24 \mathrm{~h}$ under an Ar atmosphere. The solvent was removed under reduced pressure. The residue was purified by column chromatography on silica gel with $\mathrm{CH}_{2} \mathrm{Cl}_{2} /$ ethyl acetate (10:1) to give $22(280 \mathrm{mg}, 87 \%)$ as dark green crystals. M.p. $264.0-267.0{ }^{\circ} \mathrm{C}$ decomp. $\left(\mathrm{CH}_{2} \mathrm{Cl}_{2} /\right.$ hexane); IR ( $\mathrm{KBr}$ disk): $v_{\max }=2959(\mathrm{w}), 2209(\mathrm{~m}), 1697(\mathrm{~m}), 1591(\mathrm{~m}), 1503(\mathrm{~s}), 1440(\mathrm{~s})$, $1420(\mathrm{~s}), 1383$ (m), $1330(\mathrm{~m}), 1279(\mathrm{~m}), 1212$ (s), $1191(\mathrm{~s}), 1128(\mathrm{w}), 1086$ (w), $1032(w), 972(w), 904(w), 839(w), 809(w), 777(w), 729(w), 698$ (w), $673(\mathrm{w}), 657(\mathrm{w}) \mathrm{cm}^{-1}$; UV/Vis $\left(\mathrm{CH}_{2} \mathrm{Cl}_{2}\right): \lambda_{\max }(\log \varepsilon)=243(5.01), 296$ (5.05), $394 \mathrm{sh}$ (4.83), 422 (4.89), $628 \quad(4.85) \mathrm{nm} ; \mathrm{UV} / \mathrm{Vis} \quad(50 \%$ $\mathrm{CH}_{2} \mathrm{Cl}_{2} /$ hexane): $\lambda_{\max }(\log \varepsilon)=243$ (4.99), 296 (5.02), 394 sh (4.83), 419 (4.89), $617(4.83) \mathrm{nm} ;{ }^{1} \mathrm{H}$ NMR (500 MHz, $\left.\mathrm{CDCl}_{3}\right): \delta_{\mathrm{H}}=9.88(\mathrm{~d}, 3 \mathrm{H}, J=$ $1.5 \mathrm{~Hz}, 4-\mathrm{H}), 8.28$ (d, 3H, $J=10.0 \mathrm{~Hz}, 8-\mathrm{H}), 8.15$ (s, 3H, 2-H), 8.02 (d, 3H, $J=10.0 \mathrm{~Hz}, 6-\mathrm{H}), 7.72$ (d, 6H, $\left.J=8.0 \mathrm{~Hz}, 2^{\prime}, 6^{\prime}-\mathrm{H}\right), 7.67$ (dd, $1 \mathrm{H}, J=10.0$, $10.0 \mathrm{~Hz}, 7-\mathrm{H}), 7.19-7.13\left(\mathrm{~m}, 12 \mathrm{H}, \mathrm{H}_{\mathrm{DCNQ}}\right.$ and $\left.3^{\prime}, 5^{\prime}-\mathrm{H}\right), 7.07-7.01(\mathrm{~m}, 6 \mathrm{H}$, 
$\mathrm{H}_{\mathrm{DCNQ}}$ ), 3.96 (s, 9H, CO $2 \mathrm{Me}$ ), 3.31 (sept, $\left.1 \mathrm{H}, J=7.0 \mathrm{~Hz}, i \mathrm{Pr}\right), 1.47$ (d, $18 \mathrm{H}$, $J=7.0 \mathrm{~Hz}, i \operatorname{Pr}) \mathrm{ppm} ;{ }^{13} \mathrm{C} \mathrm{NMR}\left(125 \mathrm{MHz}, \mathrm{CDCl}_{3}\right): \delta_{\mathrm{C}}=170.23\left(\mathrm{C}_{\mathrm{DCNQ}}\right)$, $164.64\left(\mathrm{CO}_{2} \mathrm{Me}\right), 155.10(\mathrm{C}-5), 153.62\left(C=\mathrm{C}(\mathrm{CN})_{2}\right), 149.25\left(\mathrm{C}-1^{\prime}\right), 145.13$ $\left(C=\mathrm{C}(\mathrm{CN})_{2}\right), 144.75(\mathrm{C}-8 \mathrm{a}), 143.82(\mathrm{C}-3 \mathrm{a}), 143.05(\mathrm{C}-2), 141.87$ (C-6), 140.29 (C-4), 136.37 (C-8), 136.15 ( $\left.\mathrm{C}_{\mathrm{DCNQ}}\right), 133.68\left(\mathrm{C}_{\mathrm{DCNQ}}\right), 133.25$ (C-4'), $131.78\left(\mathrm{C}-2^{\prime}, 6^{\prime}\right), 131.19(\mathrm{C}-7), 131.01,125.78\left(\mathrm{C}_{\mathrm{DCN} \mathrm{Q}}\right), 125.32\left(\mathrm{C}_{\mathrm{DCN} \mathrm{Q}}\right)$, 124.84 (C-3',5'), 124.17 (C-1), 119.13 (C-3), $114.07(\mathrm{CN}), 113.96(\mathrm{CN})$, $113.24(\mathrm{CN}), 112.27(\mathrm{CN}), 85.93\left(C(\mathrm{CN})_{2}\right), 74.94\left(C(\mathrm{CN})_{2}\right), 51.72$ $\left(\mathrm{CO}_{2} \mathrm{Me}\right), 39.38$ (iPr), 24.48 (iPr) ppm; HRMS (FAB) calcd for $\mathrm{C}_{105} \mathrm{H}_{69} \mathrm{~N}_{13} \mathrm{O}_{6}^{+}[\mathrm{M}]^{+}$1607.5489, found 1607.5481; Anal. Calcd for $\mathrm{C}_{105} \mathrm{H}_{69} \mathrm{~N}_{13} \mathrm{O}_{6} \cdot \mathrm{H}_{2} \mathrm{O}$ (1608.76): C, 77.52; H, 4.40; N, 11.19. found: C, 77.65; $\mathrm{H}, 4.52 ; \mathrm{N} 11.12$.

Supporting Information (see footnote on the first page of this article): Copies of ${ }^{1} \mathrm{H}$ and ${ }^{13} \mathrm{C}$ NMR, UV/Vis spectra and continuous change in the visible spectra of the reported compounds.

\section{Acknowledgments}

This work was partially supported by a Grant-in-Aid for Research (Grant 22850007 and 25810019 to T.S.) from the Ministry of Education, Culture, Sports, Science, and Technology, Japan.

[1] a) J. Kido, Y. Okamoto, Chem. Rev. 2002, 102, 2357-2368; b) A. C. Grimsdale, K. L. Chan, R. E. Martin, P. G. Jokisz, A. B. Holmes, Chem. Rev. 2009, 109, 897-1091; c) M. Zhu, J. Zou, X. He, C. Yang, H. Wu, C. Zhong, J. Qin, Y. Cao, Chem. Mater. 2012, 24, 174-180; d) Y. Zhang, S.-L. Lai, Q.-X. Tong, M.-F. Lo, T.-W. Ng, M.-Y. Chan, Z.-C. Wen, J. He, K.-S. Jeff, X.-L. Tang, W.-M. Liu, C.-C. Ko P.-F. Wang, C.-S. Lee, Chem. Mater. 2012, 24, 61-70; e) Y. Liu, S. Chen, J. W. Y. Lam, P. Lu, R. T. K. Kwok, F. Mahtab, H. S. Kwok, B. Z. Tang, Chem. Mater. 2011, 23, 2536-2544.

[2] a) J. Rivnay, S. C. B. Mannsfeld, C. E. Miller, A. Salleo, M. F. Toney, Chem. Rev. 2012, 112, 5488-5519; b) S. Feser, K. Meerholz, Chem. Mater. 2011, 23, 5001-5005.

[3] a) S.-C. Lo, P. L. Burn, Chem. Rev. 2007, 107, 1097-1116; b) Y.-J. Cheng, S.-H. Yang, C.-S. Hsu, Chem. Rev. 2009, 109, 5868-5923; c) X. Ren, S. Jiang, M. Cha, G. Zhou, Z.-S. Wang, Chem. Mater. 2012 24, 3493-3499; d) W. Z. Yuan, Y. Gong, S. Chen, X. Y. Shen, J. W. Y. Lam, P. Lu, Y. Lu, Z. Wang, R. Hu, N. Xie, H. S. Kwok, Y. Zhang, J. Z. Sun, B. Z. Tang, Chem. Mater. 2012, 24, 1518-1528; e) Y. Sun, S.-C. Chien, H.-L. Yip, Y. Zhang, K.-S. Chen, D. F. Zeigler, F.-C. Chen, B. Lin, A. K.-Y. Jen, Chem. Mater. 2011, 23, 5006-5015.

[4] a) X.-D. Zhuang, Y. Chen, B.-X. Li, D.-G. Ma, B. Zhang, Y. Li, Chem. Mater. 2010, 22, 4455-4461; b) W.-Y. Lee, T. Kurosawa, S.-T. Lin, T. Higashihara, M. Ueda, W.-C. Chen, Chem. Mater. 2011, 23, 4487-4497; c) Q.-D. Ling, D.-J. Liaw, C. Zhu, D. S.-H. Chan, E.-T. Kang, K.-G. Neoh, Prog. Polym. Sci. 2008, 33, 917-978; d) K.-L. Wang, Y.-L. Liu, I.-H. Shin, K.-G. Neoh, E.-T. Kang, J. Polym. Sci., Part A Polym. Chem. 2010, 48, 5790-5800; e) K.-L. Wang, Y.-L. Liu, J.-W. Lee, K.-G. Neoh, E.-T. Kang, Macromolecules 2010 43, 7159-7164.

[5] a) A. Leliege, P. Blanchard, T. Rousseau, J. Roncali, Org. Lett., 2011, 13, 3098-3101; b) J. Wu, J. Liu, T. Zhou, S. Bo, L. Qiu, Z. Zhen, X. Liu, $R S C A d v$., 2012, 2, 1416-1423; c) A. R. Morales, A. Frazer, A W. Woodward, H.-Y. Ahn-White, A. Fonari, P. Tongwa, T. Timofeeva, K. D. Belfield, J. Org. Chem. 2013, 78, 1014-1025.

[6] a) S. Kato, F. Diederich, Chem. Commun. 2010, 46, 1994-2006; b) M. Kivala, F. Diederich, Acc. Chem. Res. 2009, 42, 235-248; c) M. Kivala, T. Stanoeva, T. Michinobu, B. Frank, G. Gescheidt, F. Diederich, Chem. Eur. J. 2008, 14, 7638-7647; d) B. B. Frank, B. C. Blanco, S. Jakob, F. Ferroni, S. Pieraccini, A. Ferrarini, C. Boudon, J.-P. Gisselbrecht, P. Seiler, G. P. Spada, F. Diederich, Chem. Eur. J. 2009, 15, 9005-9016; e) P. Fesser, C. Iacovita, C. Wäckerlin, S. Vijayaraghavan, N. Ballav, K. Howes, J.-P. Gisselbrecht, M. Crobu, C. Boudon, M. Stchr, T. A. Jung, F. Diederich, Chem. Eur. J. 2011, 17, 5246-5250; f) B. Breiten, Y.-L. Wu, P. D. Jarowski, J.-P. Gisselbrecht, C. Boudon, M. Griesser, C. Onitsch, G. Gescheidt, W. B. Schweizer, N. Langer, C. Lennartz, F. Diederich, Chem. Sci., 2011, 2, 88-93; g) A. R. Lacy, A. Vogt, C. Boudon, J.-P
Gisselbrecht, W. B. Schweizer, F. Diederich, Eur. J. Org. Chem., 2013, 869-879; h) B. H. Tchitchanov, M. Chiu, M. Jordan, M. Kivala, W. B. Schweizer, F. Diederich, Eur. J. Org. Chem., 2013, 3729-3740.

[7] a) T. Michinobu, Chem. Soc. Rev. 2011, 40, 2306-2316; b) Y. Yuan, T. Michinobu, J. Polym. Sci. Part A Polym. Chem., 2011, 49 225-233; c) H. Fujita, K. Tsuboi, T. Michinobu, Macromol. Chem. Phys. 2011, 212, 1758-1766; d) Y. Washino, T. Michinobu, Macromol. Rapid Commun. 2011, 32, 644-648; e) Y. Li, M. Ashizawa, S. Uchida, T. Michinobu, Macromol. Rapid Commun. 2011, 32, 1804-1808; f) T. Michinobu, C. Seo, K. Noguchi, T. Mori, Polym. Chem., 2012, 3, 1427-1435; g) Y. Li, M. Ashizawa, S Uchida, T. Michinobu, Polym. Chem., 2012, 3, 1996-2005; h) T. Michinobu, Syn. Org. Chem. Jpn., 2013, 71, 149-157.

[8] a) T. Shoji, S. Ito, K. Toyota, M. Yasunami, N. Morita, Chem. Eur. J. 2008, 14, 8398-8408; b) T. Shoji, S. Ito, K. Toyota, T. Iwamoto, M. Yasunami, N. Morita, Eur. J. Org. Chem. 2009, 4316-4324; c) T. Shoji, M. Maruyama, S. Ito, N. Morita, Bull. Chem. Soc. Jpn. 2012, 85, 761-773; d) T. Shoji, S. Ito, T. Okujima, N. Morita, Org. Biomol. Chem., 2012, 10, 8308-8313; e) T. Shoji, S. Ito, T. Okujima, N. Morita, Chem. Eur. J. 2013, 19, 5721-5730.

[9] a) T. Shoji, J. Higashi, S. Ito, T. Okujima, M. Yasunami, N. Morita Chem. Eur. J. 2011, 17, 5116-5129; b) T. Shoji, J. Higashi, S. Ito, T. Okujima, M. Yasunami, N. Morita, Org. Biomol. Chem. 2012, 10, $2431-2438$

[10] T. Shoji, S. Ito, T. Okujima, N. Morita, Eur. J. Org. Chem. 2011, 5134-5140.

[11] J.-P. Corbet, G. Mignani, Chem. Rev. 2006, 106, 2651-2710.

[12] R. Boothe, C. Dial, R. Conaway, R. M. Pagni, G. W. Kabalka, Tetrahedron Lett. 1986, 27, 2207-2210.

[13] a) S. M. Hubig, W. Jung, J. K. Kochi, J. Org. Chem. 1994, 59, 6233-6244; b) T. Mukaiyama, H. Kitagawa, J. Matsuo, Tetrahedron Lett. 2000, 41, 9383-9386.

[14] a) K. J. Edgar, S. N. Falling, J. Org. Chem. 1990, 55, 5287-5291; b) G. A. Olah, G. Q. W. Sandford, P. G. K. Surya, J. Org. Chem. 1993 58, 3194-3195; c) M. C. Carreno, J. L. G. Ruano, A. G. S.Miguel, A. Urbano, Tetrahedron Lett. 1996, 37, 4081-4084; d) A. S. Castanet, F. Colobert, P. E. Broutin, Tetrahedron Lett. 2002, 43, 5047-5048.

[15] T. Yamamoto, K. Toyota, N. Morita, Tetrahedron Lett. 2010, 51, $1364-1366$

[16] S. Kajigaeshi, T. Kakinami, H. Yamasaki, S. Fujisaki, T. Okamoto, Bull. Chem. Soc. Jpn. 1988, 61, 600-602.

[17] a) Z.-H. Zhao, H. Jin, Y.-X. Zhang, Z. Shen, D.-C. Zou, X.-H. Fan, Macromolecules 2011, 44, 1405-1413; b) Y. Wu, H. Guo, T. D. James, J. Zhao, J. Org. Chem. 2011, 76, 5685-5695.

[18] Y. Shirota, T. Kobata, N. Noma, Chem. Lett. 1989, 18, 1145-1148.

[19] T. Shoji, E. Shimomura, M. Maruyama, S. Ito, T. Okujima, N. Morita, Eur. J. Org. Chem. 2013, 957-964.

[20] a) K. Sonogashira, Y. Tohda, N. Hagihara, Tetrahedron Lett. 1975 16, 4467-4470; b) S. Takahashi, Y. Kuroyama, K. Sonogashira, N. Hagihara, Synthesis 1980, 627-630; c) K. Sonogashira, Coupling reactions between $\mathrm{sp}^{2}$ and $\mathrm{sp}$ carbon centers, in Comprehensive Organic Synthesis, vol. 3 (Eds.: B. M. Trost, I. Fleming), Pergamon, Oxford, 1991, chapter 2.4, p. 521-549; d) K. Sonogashira, Cross-coupling reactions to sp carbon atoms, in Metal-Catalyzed Cross-Coupling Reactions (Eds.: F. Diederich, P. J. Stang), Wiley-VCH, Weinheim, Germany, 1998, chapter 5, p. 203-229.

[21] M. Jordan, M. Kivala, C. Boudon, J.-P. Gisselbrecht, W. B Schweizer, P. Seiler, F. Diederich, Chem. Asian J. 2011, 6, 396-401.

[22] M. Kivala, C. Boudon, J.-P. Gisselbrecht, P. Seiler, M. Gross, F. Diederich, Chem. Commun. 2007, 4731-4733.

[23] a) P. Suppan, N. Ghoneim, Solvatochromism, Royal Society of Chemistry, Cambridge, 1997; b) P. Suppan, J. Photochem. Photobiol., A, 1990, 50, 293-330; c) C. Reichardt, Solvent and Solvent Effects in Organic Chemistry, Wiley-VCH, New York, 2004.

[24] The B3LYP/6-31G(d) time-dependence density functional calculations were performed with Spartan'10, Wavefunction, Irvine, CA. 
[25] (a) S. Ito, N. Morita, Eur. J. Org. Chem. 2009, 4567-4579; (b) S. Ito, T. Shoji, N. Morita, Synlett 2011, 16, 2279-2298.

Received: ((will be filled in by the editorial staff)) Published online: ((will be filled in by the editorial staff)) 
Entry for the Table of Contents ((Please choose one layout.))

Azulene Chemistry

1-Ethynylazulenes connected by several arylamine cores reacted with TCNE and TCNQ in a formal [2+2] cycloaddition to afford the corresponding tetracyanobutadiene and dicyanoquinodimethane chromophores, respectively. The redox behavior of the novel chromophores was examined by cyclic voltammetry, which revealed their multistep electrochemical reduction properties. Moreover, a significant color changes were observed by visible spectroscopy under the electrochemical reduction conditions.

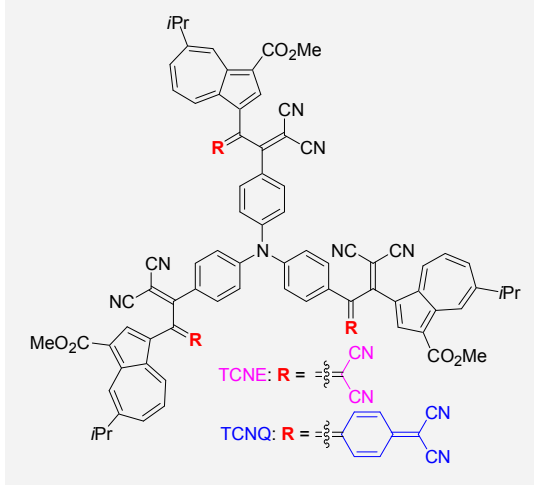

Taku Shoji,* Erika Shimomura, Mitsuhisa Maruyama, Akifumi Maruyama, Shunji Ito, Tetsuo Okujima, Kozo Toyota, and Noboru Morita ......... Page No. - Page No.

Synthesis and Properties of Azulene-substituted Donor-Acceptor Chromophores Connected by Arylamine Cores

Keywords: Azulene / Arylamine / $\pi$-Conjugate system / Cycloaddition / Redox chemistry 
